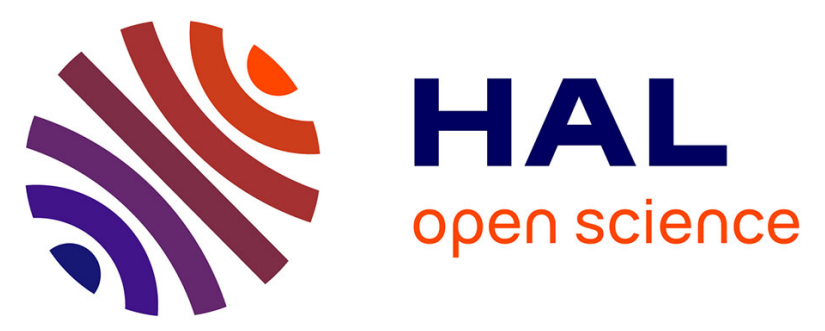

\title{
Risk management and policy implications for concentrating solar power technology investments in Tunisia
}

Damien Bazin, Nouri Chtourou, Amna Omri

\section{To cite this version:}

Damien Bazin, Nouri Chtourou, Amna Omri. Risk management and policy implications for concentrating solar power technology investments in Tunisia. Journal of Environmental Management, 2019, 237, pp.504-518. hal-02061788

\author{
HAL Id: hal-02061788 \\ https://hal.science/hal-02061788
}

Submitted on 22 Oct 2021

HAL is a multi-disciplinary open access archive for the deposit and dissemination of scientific research documents, whether they are published or not. The documents may come from teaching and research institutions in France or abroad, or from public or private research centers.
L'archive ouverte pluridisciplinaire $\mathbf{H A L}$, est destinée au dépôt et à la diffusion de documents scientifiques de niveau recherche, publiés ou non, émanant des établissements d'enseignement et de recherche français ou étrangers, des laboratoires publics ou privés.

\section{(ㅇ)(1) $\$$}

Distributed under a Creative Commons Attribution - NonCommerciall 4.0 International 
Title

Risk management and policy implications for concentrating solar power technology investments in Tunisia

\section{Authors' names and affiliations}

Emna Omria ${ }^{a, b, *}$, Nouri Chtourou ${ }^{\mathrm{a}}$, Damien Bazin ${ }^{\mathrm{b}}$

${ }^{\text {a }}$ University of Sfax, Faculty of economics and management of Sfax, LED, Airport road, Km 4, 3018 Sfax, Tunisia

${ }^{\mathrm{b}}$ Côte d'Azur University, CNRS, GREDEG, France

* Corresponding author

E-mail address: em.omri@gmail.com

Tel.: + 21650768421 


\begin{abstract}
Concentrating solar power (CSP) is a promising technology in Tunisia. However, its diffusion is facing many barriers which deter investments. Through the analysis of a CSP plant in Southern Tunisia by using the Global Risk Analysis (GRA) method, we try to analyze the main risks faced by investors. The main objective of this research is to identify and analyze the risks faced by CSP investors in Tunisia and develop strategies that should be adopted to accelerate the process of diffusion of this technology.

This analysis allows us to conclude that the CSP project is very exposed to political, financial, physical-chemical, legal, and strategic hazards. Moreover, we show that among the four phases of the project, the preparation phase is the most vulnerable to hazards.

In fact, the GRA method makes it possible to determine the list of the major risks, such as the risk of not obtaining permission to build a CSP plant, the risk of non compliance with the deadline, the risk of failure to achieve the expected performance, the risk of insufficient access to capital, and the risk of conflicts with local residents.

In order to de-risk CSP technology in Tunisia, we propose some strategies, such as strengthening the public-private partnerships, using participatory approaches, creating local employment, etc.
\end{abstract}

\title{
Keywords
}

Concentrating solar power; Investment risks, Global Risk Analysis; Tunisia 


\section{Introduction}

While the benefits and advantages of energy for economic development are multiple and well known, it is rather the damages related to our energy-intensive societies that deserve the greatest attention. According to a recent report prepared by the Renewable Energy Policy Network for the $21^{\text {st }}$ Century (REN21, 2018), the total final energy consumption was dominated by fossil fuels (oil, natural gas, and coal) by about 79.5\%, in 2016. Therefore, energy demand is mainly covered by the use of fossil fuels which are the main sources of greenhouse gas (GHG) emissions.

In fact, the increase of GHG concentrations in the atmosphere is the main cause of climate change. As a result, the prevention of the catastrophic consequences of the climate change requires the stabilization of the atmospheric concentration of these GHG and especially the carbon dioxide (IPCC, 2007). In this case, the challenge for all countries is to implement a transition to a safer and less carbon emitting energy system without hampering economic and social development (IEA, 2007). The transition to renewable energies (RE) is the evident solution to satisfy the increasing demand while respecting the environment and ensuring a green economic growth (Omri et al., 2015a).

Moreover, many recent reports have indicated that transition towards RE has already started as a result of the increase of the installed capacity and cost competitiveness of wind power and solar PV (IRENA, 2018; REN21, 2018). In fact, the year 2017 presented a new recordbreaking for the RE sector since it is marked by an impressive decrease of the costs, the expansion of investments, and the development of the installed capacities (REN21, 2018).

Solar energy is one of the most promising RE due to its competitive costs and its abundance in many countries (Astolfi et al., 2017; Sindhu et al., 2016). The two main solar technologies are the concentrating solar power technology (CSP) and the solar photovoltaic technology (PV) (Mekhilef et al., 2011).

The comparison of the corresponding costs of the different RE options is often based on the use of levelized cost of electricity (LCOE). This comparison leads to the fact that PV is more competitive than CSP (IEA, 2014; Pietzcker et al., 2014).

Joskow (2011) criticized the use of LCOE because it undervalues dispatchable power plants compared to the intermittent electricity generating technologies. In fact, while PV is an intermittent generating technology, CSP plants can generate dispatchable power when they are equipped with thermal storage systems. In this case, it is possible to store heat energy 
obtained during the day in order to be transformed into electricity at night, which facilitates its integration into the existent electricity grid (Brand et al., 2012; Trieb et al., 2014).

In fact, CSP technology with a thermal storage represents one of the few renewable technologies that can offer dispatchable electricity (IEA, 2010; Lilliestam et al., 2018).The assessment of the benefits and of the economic advantages of the CSP dipatchability was detailed in many studies, such as that of Poullikkas et al. (2010).

Although dispatchability is a very important asset for CSP technology, the grid stability aspect regarding the increasing penetration of RE should be treated seriously. In fact, the increase of the proportion of RE in the electricity mix can face many operational challenges, such as the voltage stability of the grid and the load balancing. Hence, it is necessary to ensure the flexibility of the grid and the development of the necessary transmission infrastructure.

Unlike CSP, solar PV is an intermittent technology which, in order to become dispatchable, needs a separate storage system like batteries. Nowadays CSP with a thermal storage is less expensive and more competitive than PV with batteries. However, the maintaining of this advantage in the future is not certain and depends a lot on the future evolution of the costs of PV cells and batteries (Lilliestam et al., 2018).

Therefore, it is clear that CSP technology with a thermal storage has many advantages compared to the solar PV and wind power. However, the reality shows that solar PV and wind power are winning the battle and there is a risk that CSP technology will remain in its small niche if the support from policymakers remains insufficient (Lilliestam et al., 2018). In fact, in 2017, the cumulative PV capacity reached 402 Giga watt (GW) compared to just $4.9 \mathrm{GW}$ for CSP (REN21, 2018).

Hence, despite the advantages of CSP technology, the achievements are modest. This fact proves that the widespread diffusion of CSP technology is facing several obstacles (del Rio et al., 2018; Haas et al., 2018) and requires an adequate support policy to take off (Lilliestam et al., 2018).

In fact, the Middle East and North Africa (MENA) region is one of the most favorable regions for large-scale solar energy deployment. Moreover, the high direct normal irradiation (DNI) in North Africa can make this region a major exporter of the electricity produced by CSP plants in the desert and then transmitted to Europe (IEA, 2010). For these reasons, the feasibility and financing aspects of the export of electricity produced by CSP technology in North Africa have attracted the attention of several researchers, such as Kost et al. (2011), 
Trieb et al. (2012, 2011), Viebahn et al. (2011), Williges et al. (2010), etc. Moreover, the advantage of the thermal storage can make the electricity produced by CSP plants an important component of the future electricity mix. Therefore, the African deserts will be a source of baseload and dispatchable power (Pfenninger et al., 2014; Trieb et al., 2014).

For these reasons, there are many studies that focus on CSP technology in the MENA region, especially the barriers and risks hindering its large scale development (Komendantova et al., 2012; Lilliestam et al., 2012). Morocco has attracted the attention of many researchers. However, to our best knowledge, there has not been yet any study that deals with barriers and risks of investing in CSP technology in Tunisia.

In fact, Tunisia enjoys a great potential of solar resources and many suitable factors for large scale deployment of CSP technology (Balghouthi et al., 2016). However, there are no achievements that are in harmony with the enormous solar potential of this country. In 2017, the cumulative installed capacity of solar PV accounted for about 47.1 Megawatt electric (MWe) and there has not been yet any large-scale operational CSP plant in Tunisia (IRENA Resource, 2018). Nevertheless, there are many planned plants, such as a parabolic trough plant of $50 \mathrm{MW}$ and another one of 2,500 MW using a power tower technology. Although these projects were planned many years ago, the construction has not begun yet.

Furthermore, despite the advantages that can be offered by the use of CSP technology in Tunisia, achievements in this field are inexistent. This fact leads us to set the following questions: what are the most challenging barriers that hinder CSP investments in Tunisia? In other words, what are the risks of investing in CSP technology in Tunisia? And what are the effective policy measures to mitigate these risks?

To answer these questions, we used a risk management approach and particularly a Global Risk Analysis (GRA) method in order to assess the risks concerning the case of a CSP plant that will take place in the South of Tunisia.

As a consequence, our study is structured as follows. The theoretical background is presented in section 2. Section 3 is devoted to the current status of CSP technology. The Barriers facing the CSP expansion are detailed in section 4. Then, section 5 describes the case study of the CSP plant, introduces the GRA method that will be applied, and explains all the steps required for the application of this method. The results are described in section 6 along with a related discussion and suggestions in terms of policy implications. Finally, the concluding remarks are provided in section 7 . 


\section{Theoretical background}

Climate change is a serious threat to the well-being of future generations and economic growth. To deal with this threat, it is necessary to reduce GHG emissions by using adaptation and mitigation measures in order to move to a low carbon economy (IPCC, 2007). However, the current energy system appears to be highly dependent on fossil fuels and the process of transition to RE is relatively slow mainly in the heating, cooling, and transport sectors (REN21, 2018).

This section will focus on the transition to RE, the barriers facing this process, particularly the "carbon lock-in" effect, and finally the importance of RE policy in eliminating these barriers.

\subsection{The transition to $\mathbf{R E}$}

RE satisfy the same needs as conventional energies. Indeed, they can be used to generate electricity; in this case they can supply electricity to farms, homes and buildings. RE can also be used for heating, cooling, and transport (REN21, 2018). Besides, RE can offer rural areas the opportunity of access to clean and decentralized energy sources (OECD, 2012).

In recent years, the transition to RE has been motivated by two main reasons. The first one is linked to the growing concern with sustainable development (Elum and Momodu, 2017; González et al., 2017; Omri et al., 2015b). The second reason concerns the great attention given to the concepts of "green recovery" and "green growth" since the economic crisis of 2008 (Omri et al., 2015a).

The reduction of GHG (Goh and Ang, 2018) and the creation of green jobs (Fragkos and Paroussos, 2018) are among the most known advantages of the transition to RE. Although the benefits of RE use are well known and efforts for large-scale exploitation are provided in many countries, fossil fuels still dominate (REN21, 2018). In fact, theoretical arguments and empirical research studies indicated that the current energy system is locked-in a complex context of high-carbon technologies and infrastructures (Arentsen, et al., 2002; Davis et al., 2010; IEA, 2011; Rip and Kemp, 1998; Schmidt and Marschinski, 2009).

Moreover, despite the awareness of the damage caused by the use of fossil fuels, the industrialized economies are in a locked-in position in favor of fossil fuels (Unruh, 2000) and attempts to turn to RE are facing many barriers (Painuly, 2001). In fact, the main barrier to the rapid diffusion of RE is the carbon lock-in effect which creates a market and policies that can slow down or even block the spread of RE technologies, even though they have many 
environmental and economic benefits (Unruh, 2002; 2000). This concept will be explained in the following sub-section.

\subsection{The carbon lock-in effect}

The technological lock-in effect has been increasingly explained by many researchers since the mid-1980s (Arthur, 1989; Cowan, 1990; David, 1985; Liebowitz and Margolis, 1995; Perkins, 2003). The explanations given for the existence of the technological lock-in effect are: the existence of technological paradigms and the increasing returns to adoption.

The first explanation of the technological lock-in effect is the fact that the features and the orientation of technological progress are strongly influenced by the cognitive framework of the actors in the technological community. Nelson and Winter (1977) used the term "technological regime" to characterize these frameworks, while Dosi (1982) used the term "technological paradigm". Although the terms used are different, their senses are quite similar.

According to Perkins (2003), the consequence of the existence of these mental frameworks called technological paradigms or technological regimes is that the efforts made to bring forward the efficiency of technology often focus on specific and well-defined directions which are based on past accomplishments, common beliefs and state of knowing of the technological community. This situation can create powerful exclusionary effects on innovative technological possibilities and solutions outside the "dominant technological paradigm". This "exclusion effect" was explained by Dosi (1982).

The second explanation given to the technological lock-in effect, which is strongly linked to the first one, is the presence of increasing returns to adoption which represent a positive feedback process and make an adopted technology more attractive than a new one. This idea was well explained by Arthur (1989) and David (1985) who believe that in a situation where many technologies are competing, the existence of increasing returns implies that the technology that has benefited from initial adoption advancement may eventually be more performing. There are generally four classes of increasing adoption returns that are involved in the technological lock-in effect. These four classes are: economies of scale, learning economies, adaptive expectations, and network economies (Arthur, 1994).

Recently, the technological lock-in concept has interested many researchers who are involved in the fields of technological change and the environment. These researchers highlighted the negative effects of the use of fossil fuels on climate change and the barriers facing 
industrialized economies in moving to a low-carbon energy system. This problem is caused by the carbon lock-in effect (Kemp, 1994; Mattauch et al., 2015; Rip and Kemp, 1998; Unruh, 2000).

Indeed, since the 1990s, a growing interest has been given to the effect of carbon lock-in, which is considered as an obstacle to the transition to low-carbon technologies (Ayres 1991; Freeman and Soete 1997; Kemp 1994; Unruh 2000). Mattauch et al. (2015) confirmed that the major obstacle to the transition to a low-carbon economy is the carbon lock-in effect. They considered that fossil fuels dominate the market although their alternatives, mainly RE, are dynamically more efficient.

On the other hand, Pinkse and Buuse (2012) considered that past investments in fossil fuels can influence the perception of decision-makers in oil companies about the risk-return couple, bringing them to see more opportunities in their previous trajectory than in the less familiar RE trajectory.

It should be emphasized that the carbon lock-in situation is not a permanent situation but rather a persistent state that creates barriers to fossil fuel alternatives (Unruh, 2000). Indeed, this effect is manifested in reality by a situation in which investments in RE projects face several barriers of different types (economic, institutional, financial, social, etc.) which represent significant risks for investors. In the next sub-section, we will focus on the necessity of RE policy to eliminate these barriers and to accelerate RE development.

\subsection{The role of RE policy}

Policy makers either in the developed or developing countries are promoting RE technologies by implementing specific policies which include fiscal incentives, targets, public support, and new regulations. By the end of 2017, 179 countries had set RE goals (REN21, 2018).

The main barrier to RE diffusion is its high cost compared to conventional sources (Mezher et al., 2012). Therefore, the expansion of the RE sector requires government support either through fiscal incentives, targets, public financial support, and regulations to encourage investment in this sector (REN21, 2018), or through other instruments, such as the elimination of perverse subsidies and the internalization of negative environmental externalities caused by fossil fuels (Unruh, 2000).

Although the costs have significantly declined in recent years, RE technologies still require support schemes to keep this trend. In fact, in 2017, the global weighted average LCOE of onshore wind plants reached USD 0.06/kilowatt-hours $(\mathrm{kWh})$, while for utility-scale of solar 
PV was around USD 0.10/kWh. However, CSP technology has been dragging out for many years, by having a global weighted average LCOE around USD 0.22/kWh (IRENA, 2018).

Despite the abundance of RE resources, their share remains modest due probably to the smallscale production, the insufficient learning effects, and the lack of institutional support. The government policy based on goals, strategies and instruments is very important for the development of RE. In fact, Research and Development (R\&D) subsidies and the creation of market niches are recommended to stimulate these new options (Kemp, 1994).

Researchers and analysts who studied and evaluated RE support systems used many different ways to describe and classify them. The most used typology is the one that differentiates between price-based and quantity-based instruments (Menanteau et al., 2003). In fact, the instruments and mechanisms used to accelerate the diffusion of RE are various, they include: Renewable Porfolio Standard (Xin-gang et al., 2018), Green Certificates (Hustveit et al., 2017), Feed-in Tariffs (Böhringer et al., 2017), and Renewable Obligation (Nock and Baker, 2017).

\section{Current status of CSP technology}

CSP plants produce electricity by using heat. In a similar manner as a magnifying glass, mirrors concentrate the direct solar radiation on a receiver filled with a heat transfer fluid. The heat absorbed by the fluid is used to produce steam that drives a turbine to produce electricity. Unlike solar PV technology, CSP technology has the advantage of storing heat energy for later conversion into electricity. In this case, the production of electricity in the absence of sunlight is possible by using thermal energy storage systems. This characteristic enables CSP plants to provide dispatchable power.

The CSP plants can be divided into four different technology types: parabolic troughs, linear Fresnel mirrors, central receiver systems, and dish Stirling systems. The CSP market is still dominated by parabolic troughs.

Areas favorable to the development of the CSP technology are regions that enjoy a maximum DNI, such as the MENA region, Central Asia, South Africa, South of Spain, etc. The solar limit required for potential sites is set at a DNI of at least $2,000 \mathrm{kWh} / \mathrm{m}^{2} /$ year due to economic constraints.

Unlike most natural resources, solar energy in the form of DNI exists in all continents. In addition, the populated areas are quite close and can be connected to those regions that have 
excellent solar conditions. Indeed, the electricity produced in the sunniest areas of the planet can be transmitted by means of high voltage direct current (HVDC) lines over several thousand of kilometers.

With the exception of Spain and the United States of America (USA), which are leaders in CSP technology, very few countries have large CSP facilities connected to the national electricity grid with a capacity of more than $50 \mathrm{MW}$. These countries are China, India, Morocco, South Africa, and the United Arab Emirates (UAE).

The new CSP installed capacity in 2017 was $100 \mathrm{MW}$ and the global installed capacity reached $4.9 \mathrm{GW}$ by the end of 2017 (REN21, 2018). On the other hand, Spain and the USA continue to be the leaders in terms of existing CSP capacity, but the growth of the CSP market is driven outside of these traditional markets and directed to new emerging markets, such as South Africa, India, China, and Morocco.

With the exception of Morocco and the UAE, which are key drivers of CSP expansion, the development of CSP technology in the MENA region is still below expectations regarding the enormous potentials in these countries. However, in Saudi Arabia and Kuwait, many CSP facilities are under construction which can shift the CSP activity from Spain and the USA to the MENA region in the next few years. In fact, the MENA region is one of the most favorable regions for the large-scale deployment of CSP technology. Moreover, this region is characterized by exceptional geographical features, such as high DNI, low precipitation, especially in desert areas, and the existence of flat and unused lands that are not far from power grids and roads. So, this region is very convenient for the widespread deployment of CSP technology and the export of the electricity produced to Europe using HVDC lines.

The economic impacts resulting from the development of a local industry of CSP technology in North Africa was explained in many papers. For example, Kost et al. (2012) demonstrated that the development of a CSP market in North Africa will positively influence the local economies and significantly contribute to the national gross domestic product. They actually found that total generated revenues from the potential market size of CSP plants could attain 120 Billion Euros by 2030.

\section{Barriers to CSP expansion}

The cost of CSP technology is one of the most prominent barriers to its large scale diffusion (del Rio et al., 2018). Therefore, support policies must be implemented in order to make 
investment profitable for existing firms, encourage new entrants to the CSP market, support innovation, and make CSP technology more competitive.

Lilliestam et al. (2018) considered that the CSP industry is facing two crucial risks. The first one is that many experienced firms leave the CSP market, which leads to the loss of a lot of tacit knowledge, know-how, and experience. The second risk is that developers and operators ignore innovations by using well-known components in order to avoid technology risks. This attitude is a great barrier to cost reduction.

On the other hand, the financing risk is among the risks that have attracted much attention. For example, Lilliestam et al. (2012) considered that, among the major barriers to scaling-up CSP technology, there are the expansion of electricity transmission lines and financing risks. In fact, the lack of experience with CSP investment in most emerging economies increases financing risks. Indeed, these countries are suffering from small financial markets, which are not convenient for financing large scale CSP plants, especially in terms of high interest rates and the absence of debts with long maturities (Stadelmann et al., 2014). In this case, reducing these risks is necessary to encourage developers and scale-up private investments.

Technical risks are also of a great importance. Indeed, Amato et al. (2011) carried out a very original study by assessing the risks associated with business interruption and loss of assets resulting from the emergence of undesirable internal or external events. These authors identified a list of critical hazards, such as malfunction of the orientation system, turbine failure, turbine leakage, salt solidification, and orientation system stopping.

In fact, there are many other country-specific analyses that focused on the barriers that hamper the development of CSP technology in some countries, such as Chile (Haas et al., 2018) and China (Zongxian et al., 2012), or some other regions, like the European Union (del Rio et al., 2018) and the Sub-Saharan Africa (Labordena et al., 2017).

On the other hand, the MENA region has attracted the attention of many researchers. For example, Komendantova et al. (2012) conducted three stages of interviews with experts to investigate their perceptions of risks in the case of CSP projects in North Africa. The results of unstructured expert interviews showed that bureaucratic procedures and corruption have been identified as significant barriers by more than half of all the interviewed experts. Other risks, such as the instability of national regulations, the low level of political stability, and the absence of guarantees from national governments, have also been identified as significant barriers. 
Although political corruption and bureaucracy are considered as the main concerns of investors in North Africa (Komendantova et al., 2011), the availability of water in the MENA region is also a serious challenge that should be taken into account (Balghouthi et al., 2016; Belgasim et al., 2018; Xu et al., 2016). In fact, CSP plants require a large amount of water for the cooling process and for cleaning mirrors. However, in arid locations where the annual irradiance levels are high, there is a scarcity of water. This problem can possibly be solved by the use of dry cooling technology. For example, Trabelsi et al. (2016) showed that a CSP plant with dry cooling can reduce water consumption by $93.3 \%$.

Morocco is the country of the MENA region that has attracted much attention over the past few years. For example, Wiesinger et al. (2018) evaluated a very important technical risk which is the erosion effect on the glass due to airborne sand and dust in two sites in Morocco. This risk can increase the losses of optical energy and also the operation and maintenance costs.

On the other hand, Medina et al. (2015) showed that, for the case of companies without an earlier presence in Morocco, uncertainty, insecurity and informality are the main obstacles affecting the decision to invest in the CSP sector. Regarding companies that are already active in Morocco, financial and legal barriers are of a great importance. For the same case of Morocco, Mahia et al. (2014) conducted a survey in order to examine the potential of CSP market and barriers for establishing a CSP manufacturing industry. They also showed that policy related barriers, such as the absence of fiscal and legislative framework for CSP development, are more crucial than entrepreneurial or market barriers. However, other studies discussed rather risk reduction strategies. For example, Frisari and Stadelmann (2015) examined the importance of national policy makers and international finance institutions in de-risking CSP technology in India and Morocco. Some other studies focused on de-risking CSP investments in the MENA region. For example, Schinko and Komendantova (2016) employed an LCOE model in order to analyze the impacts of a de-risking approach on the cost of electricity from CSP in four specific North African countries (Algeria, Egypt, Morocco, and Tunisia). They showed that in order to have a weighted average cost of capital (WACC) in North Africa equivalent to that in Europe, the CSP costs should be reduced by $39 \%$. Trieb et al. (2011) proposed long term power purchase agreements as a de-risking tool for CSP investments in the MENA region. 
Although the studies that addressed risks for the case of CSP technology are multiple and treated many countries, Tunisia has not received yet the attention of researchers and there is no study that deals with CSP barriers in Tunisia.

In addition to that, the existing scientific literature has used expert interviews, literature reviews, surveys, and scenario analyses, but the GRA method has not been used yet for the case of a CSP project. In fact, using this method in an environmental study is new and innovative since there is only one published study that applies the GRA method for the case of a wind farm, which is that of Desroches et al. (2016). Actually, this method is usually used for studies in the field of chemistry, industry, and mainly medicine, such as the one by Mazeron et al. (2014).

Therefore, the aim of this paper is to fill in this gap by making two contributions to the existing literature: i) treating the barriers to CSP deployment in Tunisia; ii) using the risk management approach and particularly the GRA method for the case of a CSP project.

\section{Method and data}

In this section, we will briefly introduce the case studied which concerns a CSP plant, then we will describe all the steps of the GRA method, and we will finish by applying this method to analyze all the risks that hinder the implementation of this CSP project.

\subsection{Case study: a CSP project in Tunisia}

We chose to study the case of the first CSP export project between the Sahara region and the South of Europe. This CSP power plant will be established in Southern Tunisia, which is characterized by a favorable solar radiation level of $2,500 \mathrm{kWh} / \mathrm{m}^{2} /$ year.

The installed capacity will be 2,250 MW: a first stage of $250 \mathrm{MW}$ and a second stage of 2,000 MW. This mega CSP project consists of the construction of a CSP power plant using the solar tower technology with thermal storage, the transmission of the produced electricity to Italy using underground and sea cables, and finally the electricity sale in the European energy market.

The British developer of this CSP project estimated that the overall cost will be around 10 billion Euros. Once operating, this project will have many positive impacts on the Tunisian economy in terms of job creation and implementation of an industrial area devoted to solar technologies in Southern Tunisia since most of the components will be locally manufactured. 


\section{Table 1}

The main features of the CSP project.

\begin{tabular}{|l|l|}
\hline Location & South of Tunisia \\
\hline Annual generation & 9,000 Gigawattheure $(\mathrm{GWh})$ \\
\hline Area & 10,000 hectares \\
\hline Technology & CSP tower technology with thermal storage \\
\hline Storage equipment & Molten salt \\
\hline Status & Partially permitted \\
\hline
\end{tabular}

In fact, the feasibility study of this project began in 2009, however, until now, the construction has not started yet. The project is a perfect illustration of the existence of many barriers to the investment in CSP technology in Tunisia. In order to analyze all the barriers and risks faced by the developers, we used a risk management approach and especially the GRA method that will be explained in the next sub-section.

\subsection{The GRA method}

The GRA is a global analysis method which is used to appreciate and manage risks of different natures, such as company's risks, project risks, and product risks, following an invariable process. Its specificity depends on the nature of the considered system and the mapping of the considered hazards and not on the actual analysis process.

The GRA is the name given by Desroches (2013) to the up-to-date Preliminary Risk Analysis (PRA) method which was developed in the 1960's in the aerospace industry and recently extended to many other sectors, including military, chemistry, transport, medicine, and more recently the environment. This analysis is particularly used in health organizations and civil aviation. This paper presents the first application of the GRA for the case of a CSP plant.

In fact, the GRA is a priori (proactive), an analytical, bottom up, and semi quantitative risk analysis method (Desroches et al., 2016) which implements all the risk analysis and management steps in compliance with the ISO 31000:2018 norm (an international standard that provides principles and guidelines for risk management). Besides, it includes context establishment, risk identification, risk assessment, initial risk reduction (prevention/ protection), and residual risk assessment and management (monitoring/insurance taking). It can be used for the management of risks of different natures, such as enterprise risk, project risk, and product risk (Desroches, 2013).

Moreover, the GRA is based on the accident scenario presented in Fig.1. An accident scenario is defined as a sequence or a combination of events ending up in an accident (A) that has consequences (S). This scenario begins with the occurrence of a contact event or an 
exposition factor $(\mathrm{EF})$ which creates the exposition of the system $(\mathrm{S})$ to a hazard $(\mathrm{H})$ and therefore, creates a hazardous situation (HS). Then, the exposition of the hazardous situation (HS) to an initiating or a triggering factor (TF) leads to the accident (A). Finally, the occurrence of a circumstantial event or an aggravating factor (AF) defines and characterises the occurrence, the nature, and the severity of the consequences (S). The causes (hazard, contact event, and trigger event) are related to the parameter "likelihood" of the risk. The nature and the intensity of the consequences are related to the parameter "Severity" of the risk.

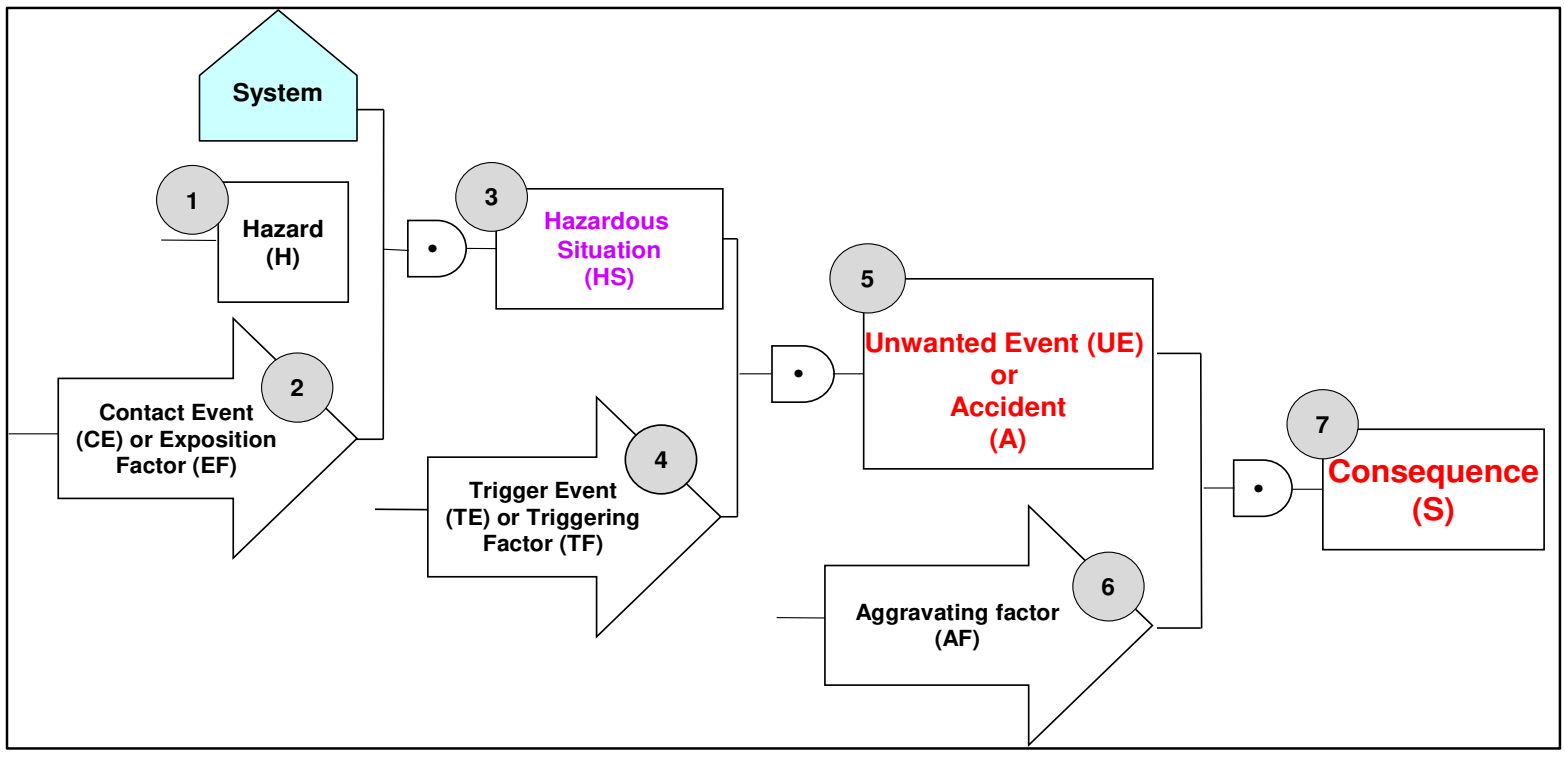

Fig 1. Accident scenario (Desroches, 2013).

The GRA process (Fig.2) contains three consecutive steps: the system GRA, the scenario GRA and the risk management. The first step consists in: (i) defining the perimeter of the studied system which is the CSP project divided into phases and sub-phases (Appendix A); (ii) identifying all the hazards that could potentially affect the implementation of the project in a hierarchical list composed of generic hazards (generic categories), specific hazards (subcategories specifically to the system) and hazardous elements/events (translation of the specific hazards in terms of events or elements); and, finally, (iii) identifying the interactions between hazardous events and sub-phases of the system leading to hazardous situations. The structure of the mapping of hazardous situations is made by the crossed juxtaposition of the system and the mapping of hazards. The hazard/system interaction is the factor that generates hazardous situations. The interactions should normally be considered as determinists.

The second step, which is the scenario GRA, consists, first of all, in defining the risk assessment parameters, such as the severity and likelihood scales (Table 3 and Table 4). The 
severity scale is based on 5 levels of decreasing severity. In compliance with basic principles of dependability, levels S5 and S4 are related to safety whereas levels S3 and S2 are related to the performance of the system (reliability/availability). Concerning the likelihood scale, it is semi-quantitative and based on 5 levels of likelihood, which can be associated with a scale of system-dependent return periods.

Once the assessment scales are identified, the criticality matrix can be built (Table 6). Finally, the scenarios are identified and described, and the associated initial risks are assessed. If needed (initial criticality $\mathrm{C} 2$ or $\mathrm{C} 3$ ), initial risk reduction actions are identified in terms of prevention (decrease of the likelihood) and protection (decrease of severity) and the subsequent residual risk is assessed. Again, if needed (residual criticality C2), residual risk management actions are defined in terms of risk control/monitoring and insurance taking (Appendix D. Scenario_GRA).

The third step, which is risk management and result dissemination, comes after data performing. Therefore, risk mappings are built (Kiviat and Farmer diagrams, but only Kiviat diagrams are presented in this paper) based on the statistical treatment of the analysis. The minimal, average and maximal risks are represented per hazards and per phases. Then, the list of 5 to 10 major risks is elaborated. Moreover, the practical management of risks is made by the drafting of action sheets and the development of an action follow-up table for initial and residual risks. The software used to perform this analysis is the version 2.091 of StatCart GRA developed by MAD-environment.
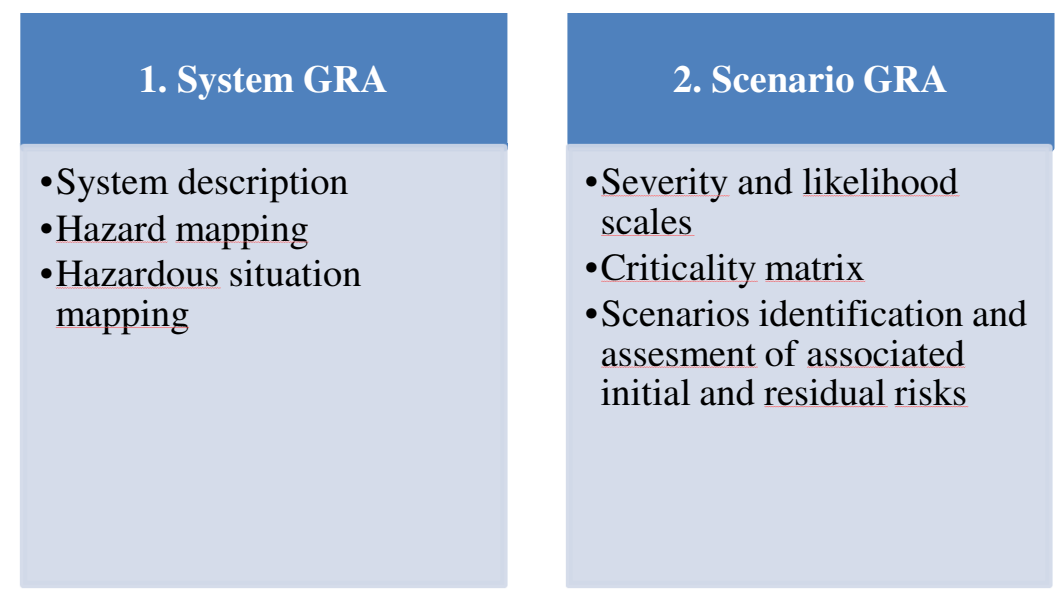

\section{Risk management and results dissemination}

- Overall results for initial and residual risks

- Risk mapping per hazard

-Risk mapping per system element

- List of top risks

-Initial risk reduction plan

- Residual risk management plan

Fig.2. The GRA process.

The GRA method requires in-depth knowledge of the studied system, which is the CSP project. For this reason, this method has been applied during a six-month internship at the National Agency for Energy Conservation (ANME: Agence Nationale pour la Maîtrise de 
l'Energie), which is the leader in the institutional organization of energy efficiency and RE in Tunisia. This internship has facilitated meetings with several experts, especially during the numerous congresses organized by the ANME during the training period. In addition, this internship has been an opportunity to benefit from the knowledge and advice of experts and engineers who are working at the ANME. We have also conducted open interviews with the chief executive officer of the project. In addition, we have used a review of the data provided by the ANME, the state electricity utility STEG (STEG: (Société Tunisienne de l'Electricité et du Gaz), and a compilation of secondary sources (books, scientific articles, reports prepared by international organizations, press articles, etc.), as well as a feedback from similar projects, such as the case of the CSP plant in Morocco.

Based on professional advice from experts, managers and engineers in the field of RE as well as experience feedback, we have been able to carry out all stages of the GRA which require a multidisciplinary team. The use of the GRA method for this case is adequate for two main reasons. The first one is that this method is a priori (proactive) risk analysis method so, it can be used to analyze risks of a project or an activity before it takes place. This is adequate to this case study since the construction of the CSP plant has not begun yet. The second reason is that the construction of this CSP plant was postponed many times and since 2009, there has been no real progress, which proves that the implementation of the project faces several barriers and risks that hinder its implementation. Hence, a risk analysis using the GRA method is needed to identify the main barriers.

\subsection{The application of the GRA method for the case of a CSP project}

In this sub-section, we will apply the two first steps of the GRA process, which are the system GRA and the scenario GRA, to the case of the CSP project while the risk management step which comes after data processing will be explained in the result section.

\subsubsection{System GRA}

The system GRA contains the following steps: the description of the CSP project (Appendix A), the elaboration of the hazard mapping (Appendix B), and finally the elaboration of the hazardous situation mapping (Appendix C. Mapping_HS).

\subsubsection{Description of the CSP project}

The first required step is a detailed description of the CSP project. In fact, a deep analysis of the CSP project enabled us to divide it into four main steps (feasibility study, preparation, construction, and operation), 20 phases, and 51 sub-phases (Appendix A). 


\subsubsection{Elaboration of the hazard mapping}

The list of generic and specific hazards has been established similarly to the one proposed by Desroches (2013), and the hazardous events have been determined according to the characteristics of the CSP project in terms of technology, operating methods, required resources, etc. Finally, we got 14 generic hazards (political, environment, insecurity, image, management, strategic, technological, communication and crises, legal, financial, infrastructure and premises, materials and equipment, information system, and physicalchemical) detailed in many hazardous events which can affect the sub-phases of the CSP project (Appendix B). In fact, the hazardous events were identified by reviewing many studies, such as those of Gabriel (2016), Otieno and Loosen (2016), Painuly (2001), international reports, press articles, feedback from similar CSP systems (for example, the CSP plant Noor in Morocco), and especially discussions with experts working in the ANME and with the chief executive officer of the project.

\subsubsection{The hazardous situation mapping}

The sub-phases of the CSP project have been confronted to the hazardous events in a double entry table in order to obtain the hazardous situation mapping (Appendix C. Mapping_HS). The development of the hazardous situation mapping is the fundamental cornerstone of the analysis since it requires a rigorous and detailed work, and especially a thorough knowledge of the studied project. In addition to that, the determination of hazardous situations is the key step that will be used to determine risk scenarios, risk maps and the list of the major risks.

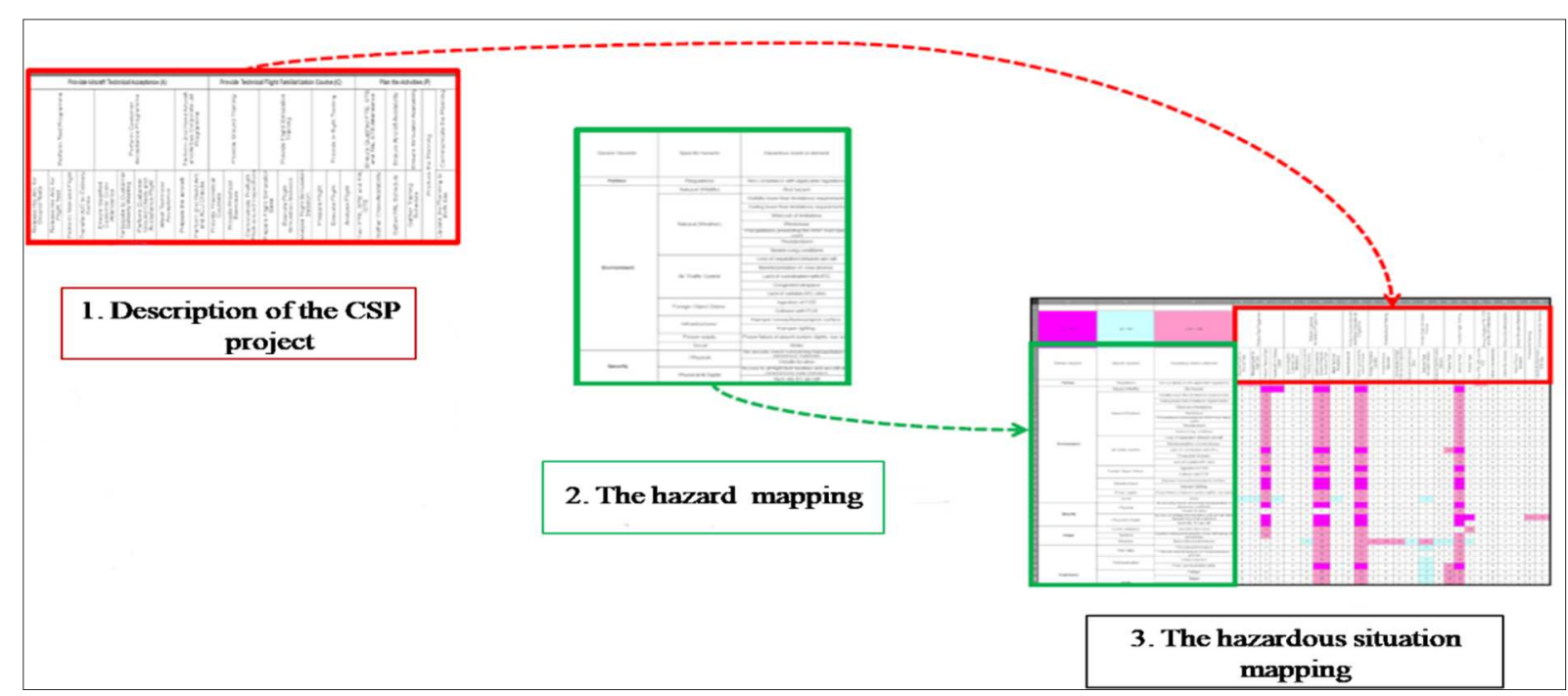

Fig. 3. The elaboration of the hazardous situation mapping. 
In fact, each interaction between a hazardous event and a vulnerable element of the system represents a hazardous situation which has been evaluated, when relevant, by assigning a priority index. Then, the hazardous situations have been classified into three priority levels according to the priority indexes explained in Table 2. For example, when the interaction between the vulnerable element of the system and the hazardous event is strong and the evaluation and treatment of this hazardous situation is needed immediately, we put a priority index " 1 " in the cell.

\section{Table 2}

The interactions between the hazards and the system.

\begin{tabular}{|c|c|c|}
\hline $\begin{array}{c}\text { Priority } \\
\text { Index (Ip) }\end{array}$ & Interaction Hazard/System & $\begin{array}{c}\text { Decision to perform an } \\
\text { analysis, an evaluation and } \\
\text { treatment }\end{array}$ \\
\hline Blank or 0 & No interaction & Immediately \\
\hline 1 & Strong to very strong interaction & Later \\
\hline 10 & Strong to very strong interaction & Afterwards \\
\hline 2 & Weak to medium interaction & \\
\hline
\end{tabular}

Source: Desroches et al. (2016)

In our study, we have been able to identify 169 hazardous situations, which have been divided into 33 hazardous situations with a priority index "1" (19\%), 62 hazardous situations with a priority index " 2 " (37\%), and 74 hazardous situations with a priority index "10" (44\%). Then, we have only analyzed hazardous situations with a priority index " 1 ".

\subsubsection{Scenario GRA}

The scenario GRA contains the following steps: the elaboration of severity and likelihood scales (Table 3 and Table 4) and criticality matrix (Table 6), and the identification of all possible scenarios according to the process explained in Fig.1 in order to obtain the scenario GRA (Appendix D. Scenario_GRA).

\subsubsection{The severity and likelihood scales}

The risk assessment is based on two aspects:

- The severity of consequences (S), which is based on a severity scale (Table 3) composed of 5 levels: S1 (insignificant, which corresponds to no real impact on mission or safety), S2 (minor or significant, which corresponds to the mission degradation without any impact on safety), S3 (major or severe, which corresponds to the mission failure without any impact on safety), S4 (hazardous or critical, which corresponds to safety degradation), and S5 (catastrophic, which corresponds to safety failure). 
- The likelihood of occurrence (L) which is based on a likelihood scale (Table 4) composed of 5 levels: L1 (extremely improbable), L2 (improbable), L3 (remote), L4 (occasional), and L5 (frequent).

The severity and likelihood scales have been developed in a working group that takes into account the experience feedback of similar projects, the data collected from different sources, and the knowledge of each member of the multidisciplinary group.

Table 3

Severity scale.

\begin{tabular}{|c|c|c|c|}
\hline Severity level & Severity name & Severity index & Description of consequences \\
\hline $\mathrm{S} 1$ & Insignificant & 1 & $\begin{array}{l}10 \text { No impact on the system performance or safety } \\
11 \text { Insignificant reduction in performance without impact on } \\
\text { activity } \\
12 \text { Inconsequential operational constraints } \\
13 \text { Temporary unavailability of structure or equipment } \\
14 \text { Injury on duty without work stoppage }\end{array}$ \\
\hline S2 & Minor & 2 & $\begin{array}{l}20 \text { Degradation of the system performance with no impact on } \\
\text { safety } \\
21 \text { Unavailability of services or equipment on the scheduled date } \\
22 \text { Unavailability of equipment, premises or staff less than one day } \\
23 \text { Injury on duty with work stoppage less than } 21 \text { days } \\
24 \text { Controllable pollution }\end{array}$ \\
\hline S3 & Major & 3 & $\begin{array}{l}30 \text { Significant degradation or failure of the system performance } \\
\text { with no impact on safety } \\
31 \text { Significant performance degradation } \\
32 \text { Very degraded or failed activity } \\
33 \text { Significant operational constraints } \\
34 \text { Significant damage to infrastructure or goods } \\
35 \text { Injury on duty with work stoppage for more than } 21 \text { days }\end{array}$ \\
\hline S4 & Hazardous & 4 & $\begin{array}{l}40 \text { Degradation of the system's safety or integrity } \\
41 \text { Severe injury or temporary disability } \\
42 \text { Partial destruction of infrastructure or assets } \\
43 \text { Significant damage to the environment } \\
44 \text { Temporary staff disability } \\
45 \text { Delay in project implementation }\end{array}$ \\
\hline S5 & Catastrophic & 5 & $\begin{array}{l}50 \text { Significant degradation or failure of the system safety or its loss } \\
51 \text { Loss of life or disability } \\
52 \text { Total destruction of infrastructure or assets } \\
53 \text { Irreversible damage to the environment } \\
54 \text { Huge financial loss } \\
55 \text { Permanent discontinuation of the project }\end{array}$ \\
\hline
\end{tabular}

The likelihood scale (Table 4) contains 5 likelihood levels associated with a recurrence period. Recurrence periods are determined according to the temporality, lifetime and technical characteristics of the CSP plant.

Table 4

Likelihood scale.

\begin{tabular}{clcl}
\hline Likelihood levels & Level name & Likelihood index & Likelihood description \\
\hline L1 & Extremely improbable & 1 & Less than once per 25 years \\
L2 & Improbable & 2 & Between once per 25 years and once per 5 years \\
L3 & Remote & 3 & Between once per 5 years and once a year \\
\hline
\end{tabular}




\begin{tabular}{llll}
\hline L4 & Occasional & 4 & Between once a year and once a month \\
L5 & Frequent & 5 & More than once a month \\
\hline
\end{tabular}

\subsubsection{The criticality matrix}

The risk criticality represents the function of decision: $C=f_{d}(S, L)$. The definition domain of $f_{d}$ is 25 couples $(S, L)$ and its domain of values is $\{C 1, C 2, C 3\}$. The criticality is the result of a decision function linked to a scale of political, social, human values, etc. (Desroches et al., 2016).

The first and most important step is to divide all the project risks into three categories according to their criticality. The criticality classes are: acceptable (C1), tolerable under control (C2), and unacceptable (C3) of respective colors: green, yellow, and red (Table 5). Each criticality class corresponds to a well-defined action.

Table 5

Criticality scale.

\begin{tabular}{|c|c|l|}
\hline $\begin{array}{c}\text { Criticality } \\
\text { level }\end{array}$ & Risk level & \multicolumn{1}{c|}{ Decisions and actions } \\
\hline $\mathrm{C} 1$ & Acceptable & Nothing needs to be done. \\
\hline $\mathrm{C} 2$ & Tolerable under control & $\begin{array}{l}\text { No action to reduce the risk is mandatory, but a close monitoring } \\
\text { needs to be implemented in terms of risk management. }\end{array}$ \\
\hline $\mathrm{C} 3$ & Unacceptable & $\begin{array}{l}\text { The risk needs to be reduced, otherwise, the activity must be } \\
\text { stopped partially or totally. }\end{array}$ \\
\hline
\end{tabular}

Source: Desroches et al. (2016)

The criticality matrix (Table 6) is a two-dimensional presentation that presents the two components of risk: likelihood versus severity. It allows the association of a criticality level to each severity-likelihood pair. Thus, a severity level S5 associated with a likelihood level L5 corresponds to a maximum criticality level C3.

Indeed, by defining the domain of unacceptability, we delimit the domain in which the risks must absolutely be refused and by defining the domain of tolerability or acceptability, we delimit the domain in which all the risks must be with or without a treatment.

Table 6

Criticality matrix.

\begin{tabular}{|c|c|c|c|c|c|c|}
\hline & \multicolumn{5}{|c|}{ Severity } \\
\hline & & 1 & 2 & 3 & 4 & 5 \\
\hline \multirow{5}{*}{ 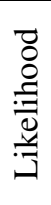 } & 5 & 1 & 2 & 3 & 3 & 3 \\
\hline & 4 & 1 & 2 & 2 & 3 & 3 \\
\hline & 3 & 1 & 1 & 2 & 2 & 3 \\
\hline & 2 & 1 & 1 & 1 & 2 & 2 \\
\hline & 1 & 1 & 1 & 1 & 1 & 1 \\
\hline
\end{tabular}


Likelihood and severity scales and criticality matrix have been used to evaluate all the risk scenarios according to the severity of consequences and likelihood of occurrence and, then, have been prioritized by criticality. The criticality of each scenario has been determined and all scenarios have been divided into 3 categories of criticalities: $\mathrm{C} 1, \mathrm{C} 2$, and $\mathrm{C} 3$. Corrective actions have been set up in order to reduce initial risks. Once the categorization of initial risks was done, corrective actions are proposed to reduce scenarios with criticality $\mathrm{C} 3$ and $\mathrm{C} 2$. The criticality of residual risks has also been re-evaluated by according a new level of criticality that integrates the impacts of the corrective actions implemented to initial risks. (Appendix D. Scenario_GRA).

\section{Results and discussions}

Once the scenario GRA is elaborated by using the hazardous situation mapping, the assessment scales and the criticality matrix, we move on to data performing by using the version 2.091 of StatCart GRA developed by MAD-environment.

The application of the GRA method to the CSP project enables us to analyze the risks that impede the implementation of this project. The results are explained in details in this section. We have just analyzed the hazardous situations with priority index " 1 " given the serious impacts they may have on the CSP project. The scenario GRA has allowed us to identify 33 risk scenarios from the 33 hazardous situations of priority index " 1 ".

In order to present the main results, we start with the distribution of hazardous situations by type of generic hazard, which enables us to identify the type of hazard that is likely to cause the highest number of hazardous situations and risk scenarios. We find that the political hazard creates the highest number of hazardous situations, which means that the political hazard must be taken seriously by the developers of this project (Table 7). Concerning the distribution of hazardous situations by project phase (feasibility study, preparation, construction, and operation), we conclude that the preparation phase of the project contains the highest number of hazardous situations (12 hazardous situations among the 33 analyzed hazardous situations). Therefore, this phase is the most affected by the different types of generic hazards and requires the most attention (Table 8).

Then, we present the distribution of risk scenarios per initial and residual criticality classes $(\mathrm{C} 1, \mathrm{C} 2$, and $\mathrm{C} 3)$. We note that the risk reduction actions explained in the scenario GRA (Appendix D. Scenario_GRA) allow us to move on from 10 initial risks with C3 criticality (Table 9) to no residual risk with C3 criticality (Table 10). 
Afterwards, we present the Kiviat diagram which provides a representation of minimal, average and maximal risks per hazard and per phase while integrating at the same time criticality. According to this diagram, the risks resulting from the legal hazard have the minimum, medium and maximum risk indexes with C3 criticality (unacceptable), which means that the risks caused by the legal hazard must be taken very seriously by investors (Fig.6). We also note that the initial risks arising from the preparation phase have an average risk index with C3 criticality, which confirms the vulnerability of this phase (Fig.7).

Finally, the GRA method allows us to determine the list of top risks, such as the risk of not obtaining permission to build the CSP plant, the risk of non compliance with deadlines, the risk of failure to achieve the expected performance, the risk of insufficient access to capital, and the risk of conflicts with local residents. We explain in details the main causes of the top risks and the convenient strategies and actions that we propose to reduce them.

\subsection{Distribution of risk scenarios per type of generic hazard and per project phase}

We note that the political hazard is likely to cause the highest number of hazardous situations and risk scenarios (10 scenarios). The physical-chemical, financial and strategic hazards generate respectively 4,3 and 3 risk scenarios (Table 7).

These findings are in line with the results of most studies, especially with regard to the importance of political and financial hazards in the MENA countries. However, this study emphasizes the physical-chemical hazard which is often neglected in RE projects.

Table 7

Number of identified hazardous situations and analyzed scenarios per generic hazard.

\begin{tabular}{|l|c|c|c|}
\hline \multicolumn{1}{|c|}{ Type of hazard } & Index & $\begin{array}{c}\text { Number of } \\
\text { hazardous situations }\end{array}$ & $\begin{array}{c}\text { Number of risk } \\
\text { scenarios }\end{array}$ \\
\hline Political & POL & 10 & 10 \\
\hline Environment & ENV & 2 & 2 \\
\hline Insecurity & INS & 1 & 1 \\
\hline Image & IMG & 1 & 1 \\
\hline Management & MAN & 2 & 2 \\
\hline Strategic & STR & 3 & 3 \\
\hline Technological & TEC & 1 & 1 \\
\hline Communication and crises & COM & 1 & 2 \\
\hline Legal & LEG & 2 & 3 \\
\hline Financial & FIN & 3 & 1 \\
\hline Infrastructure and premises & INF & 1 & 1 \\
\hline Materials and equipment & MAT & 1 & 1 \\
\hline Information system & IS & 1 & 4 \\
\hline Physico-chemical & PCH & 4 & 2 \\
\hline
\end{tabular}


The 33 hazardous situations of priority index "1", which are grouped per generic hazard type, are shown in percentages in Fig.4. This representation shows two groups of hazards that can be classified according to their relative importance:

- Hazards with prime importance: political (30\%), physical-chemical (13\%), financial (9\%), strategic (9\%), environment (6\%), management (6\%), and legal $(6 \%)$.

- Hazards with medium to low importance: material and equipment (3\%), information system (3\%), infrastructure and premises (3\%), communication and crisis (3\%), technological (3\%), insecurity (3\%), and image (3\%).

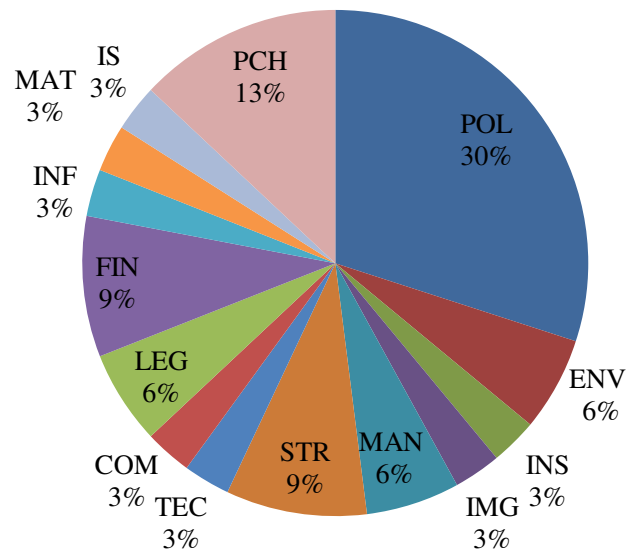

Fig. 4. Distribution of hazardous situations per generic hazard.

It is therefore clear that the CSP project is too exposed to political hazard since the latter generates the greatest part of hazardous situations. This is quite logical given the current situation in Tunisia which is characterized by political instability following the 2010 revolution and the birth of a young democracy.

\section{Table 8}

Number of identified hazardous situations and scenarios analyzed per phase of the project.

\begin{tabular}{|l|c|c|c|}
\hline Phase of the project & Index & Number of hazardous situations & Number of risk scenarios \\
\hline Feasibility study & A & 3 & 3 \\
\hline Preparation & B & 12 & 12 \\
\hline Construction & C & 8 & 8 \\
\hline Operation & D & 10 & 10 \\
\hline
\end{tabular}

Concerning the identified hazardous situations and the scenarios analyzed per project phase (Table 8), the results show that the preparation and operation phases of the CSP project contain the highest number of hazardous situations. The preparation phase is the phase the most exposed to the 14 generic hazards since it generates 12 hazardous situations of priority index " 1 ". This is due to the complexity of administrative, legal and financial procedures required to have all the necessary authorizations and agreements. Indeed, this phase is 
decisive for the implementation of the project. Moreover, for more than 6 years, the project has been blocked in this phase without any progress towards the phase of construction. These results demonstrate the delicacy of the preparation phase and its high vulnerability to the different classes of generic hazards.

The 33 hazardous situations of priority index "1" grouped per project phase are shown in percentages in Fig.5 in which the preparation and operation phases contain respectively $37 \%$ and $30 \%$ of all the identified hazardous situations, while the construction phase contains $24 \%$ and the feasibility study contains just $9 \%$ of all the hazardous situations.

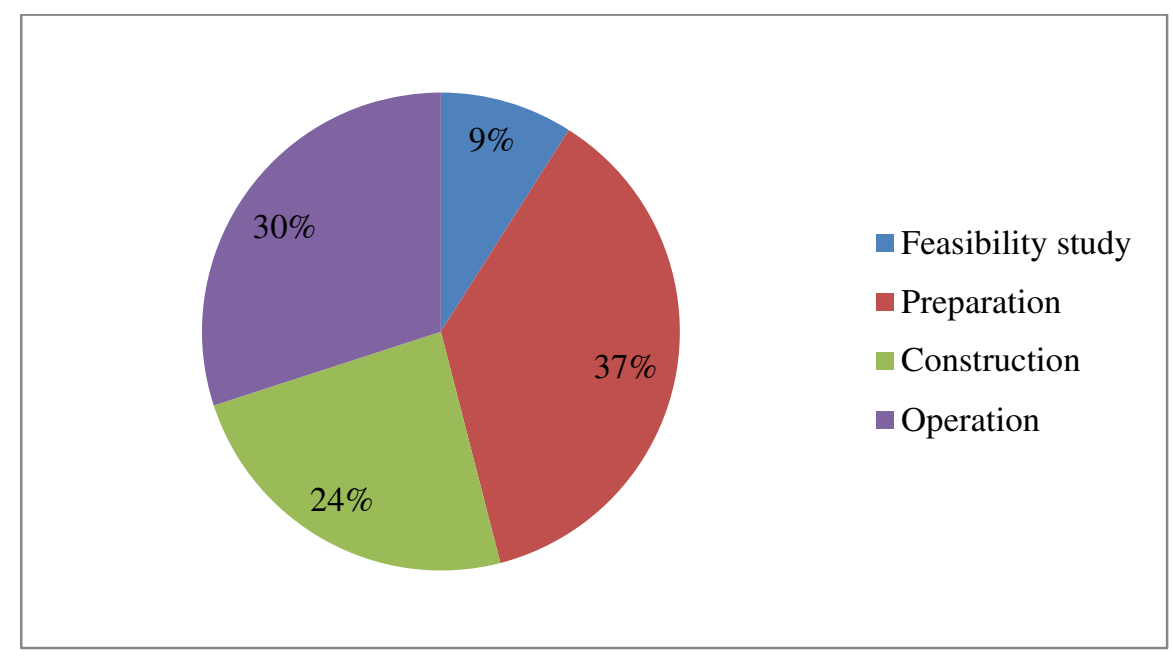

Fig. 5. Distribution of hazardous situations per project phase.

\subsection{Distribution of risk scenarios per initial and residual criticality}

The following tables (Table 9 and Table 10) present the number of risk scenarios analyzed according to the "severity-likelihood" couple, as well as before and after the actions of reduction of initial risks presented in the scenario GRA (Appendix D. Scenario_GRA). We note that before starting these actions (Table 9), we have one initial risk with C1 criticality (acceptable), 22 initial risks with $\mathrm{C} 2$ criticality (tolerable under control), and 10 initial risks with C3 criticality (unacceptable).

\section{Table 9}

The criticality matrix for initial risks.

\begin{tabular}{|c|c|c|c|c|c|c|}
\hline & \multicolumn{5}{|c|}{ Severity } \\
\hline & & 1 & 2 & 3 & 4 & 5 \\
\hline \multirow{5}{*}{ 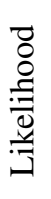 } & 5 & 1 & & 2 & & \\
\hline & 4 & & 4 & 7 & 6 & \\
\hline & 3 & & & 7 & 2 & 2 \\
\hline & 2 & & & & & 2 \\
\hline & 1 & & & & & \\
\hline
\end{tabular}

\begin{tabular}{|c|c|}
\hline $\mathrm{C} 1$ & 1 \\
\hline $\mathrm{C} 2$ & 22 \\
\hline
\end{tabular}


The risk reduction actions allow us to reduce the criticality of initial risks by reducing the likelihood or the severity, or both at the same time in order to have residual risks with $\mathrm{C} 1$ (acceptable) or $\mathrm{C} 2$ (tolerable under control) criticality and no residual risk with $\mathrm{C} 3$ criticality (unacceptable). This is well respected in our analysis since we have 23 residual risks with $\mathrm{C} 1$ criticality (acceptable), 10 residual risks with $\mathrm{C} 2$ criticality (tolerable under control), and no residual risk with $\mathrm{C} 3$ criticality (unacceptable) (Table 10).

\section{Table 10}

The criticality matrix for residual risks.

\begin{tabular}{|c|c|c|c|c|c|c|}
\hline & \multicolumn{5}{|c|}{ Severity } \\
\hline & & 1 & 2 & 3 & 4 & 5 \\
\hline \multirow{5}{*}{ 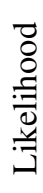 } & 5 & 1 & & & & \\
\hline & 4 & & & 2 & & \\
\hline & 3 & 4 & 7 & 6 & & \\
\hline & 2 & & 5 & 5 & 2 & \\
\hline & 1 & & & 1 & & \\
\hline
\end{tabular}

\begin{tabular}{|c|c|}
\hline $\mathrm{C} 1$ & 23 \\
\hline $\mathrm{C} 2$ & 10 \\
\hline $\mathrm{C} 3$ & 0 \\
\hline \multicolumn{2}{|c}{33} \\
\hline
\end{tabular}

\subsection{Risk mapping per hazard}

The Kiviat diagram provides an overview of the risks associated with the CSP project and facilitates their comparison. In fact, it provides a detailed analysis of the initial and residual risks per generic hazard or per project phase. This representation allows us to make the appropriate decisions according to the general context and the vulnerability of the project.

The axes of the diagram represent the 14 generic hazards. The minimum, average and maximum indexes of the different initial and residual risks are positioned on these axes. The Kiviat diagram also shows the three risk criticality areas $(\mathrm{C} 1, \mathrm{C} 2$ and $\mathrm{C} 3$, respectively with the colors green, yellow, and red). 


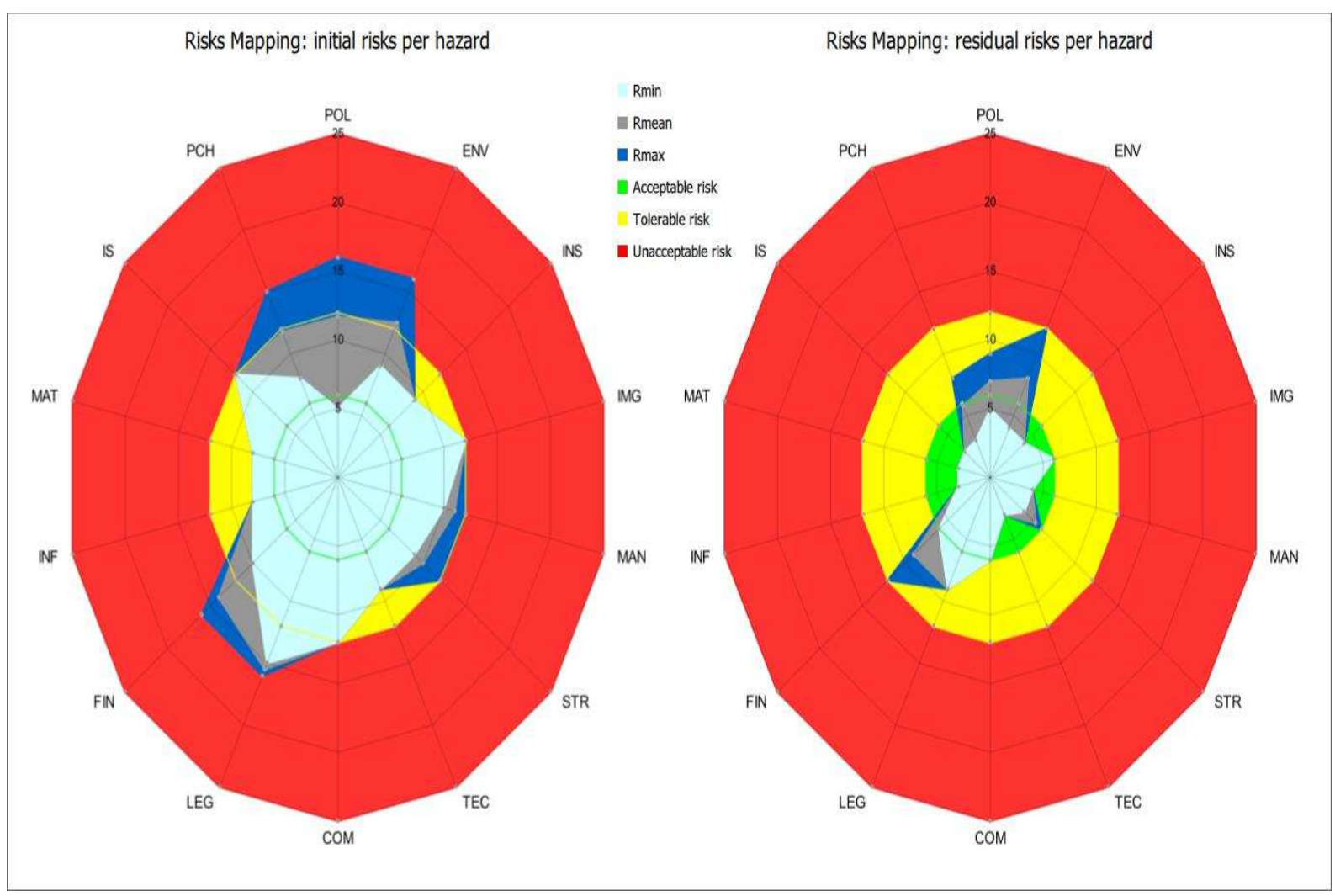

Fig. 6. Kiviat diagrams of initial and residual risks per hazard.

According to the left-sided Kiviat diagram in Fig.6, we notice that the initial risks descended from environmental, political, physical-chemical, financial, and legal hazards have a maximum risk index of $\mathrm{C} 3$ criticality. Thus, the risks arising from these types of hazards must be a priority for project developers and managers in order to avoid serious consequences.

Among these generic hazards, only the legal hazard can cause initial risks with a minimum risk index of $\mathrm{C} 3$ criticality. This leads us to note that the legal hazard must be taken very seriously by investors, since the risks resulting from this hazard have the minimum, medium and maximum risk indexes with $\mathrm{C} 3$ criticality. Thus, even if the share of risks arising from legal hazard is not very high (only 6\% compared to $30 \%$ for political hazard and $13 \%$ for physical-chemical hazard), this hazard can cause risks with catastrophic and therefore unacceptable consequences for the project.

The right-sided Kiviat diagram in Fig.6 provides an assessment of the effectiveness and magnitude of risk reduction actions. After the implementation of the initial risk reduction actions, we can make the following remarks:

- None of the residual risk indexes (minimum, average or maximum) has a C3 cirticality. Thus, the risk reduction actions implemented have succeeded in bringing all the risk indexes to $\mathrm{C} 2$ or $\mathrm{C} 1$ criticality levels. This result proves the effectiveness of the applied actions. 
- The residual risks arising from political, financial, legal and environmental hazards have an average risk index of $\mathrm{C} 2$ criticality. Thus, the residual risks arising from these hazards are tolerable under control and therefore require control actions, such as insurance.

- The residual risks resulting from the legal hazard have a minimum risk index of C2 criticality. Consequently, even after the implementation of the initial risk reduction measures, the residual risks arising from the legal hazard should always be under the continuous control and monitoring by applying control measures.

\subsection{Risk mapping per project phase}

In the case of the analysis per project phase, the axes of the Kiviat diagram (Fig.7) represent the 4 phases of the project (feasibility study (A), preparation (B), construction (C), and operation (D)) that have been presented and explained in the detailed analysis of the project. The axes also contain the minimum, average and maximum risk indexes corresponding to each phase of the project. The Kiviat diagram also shows the three criticality areas.

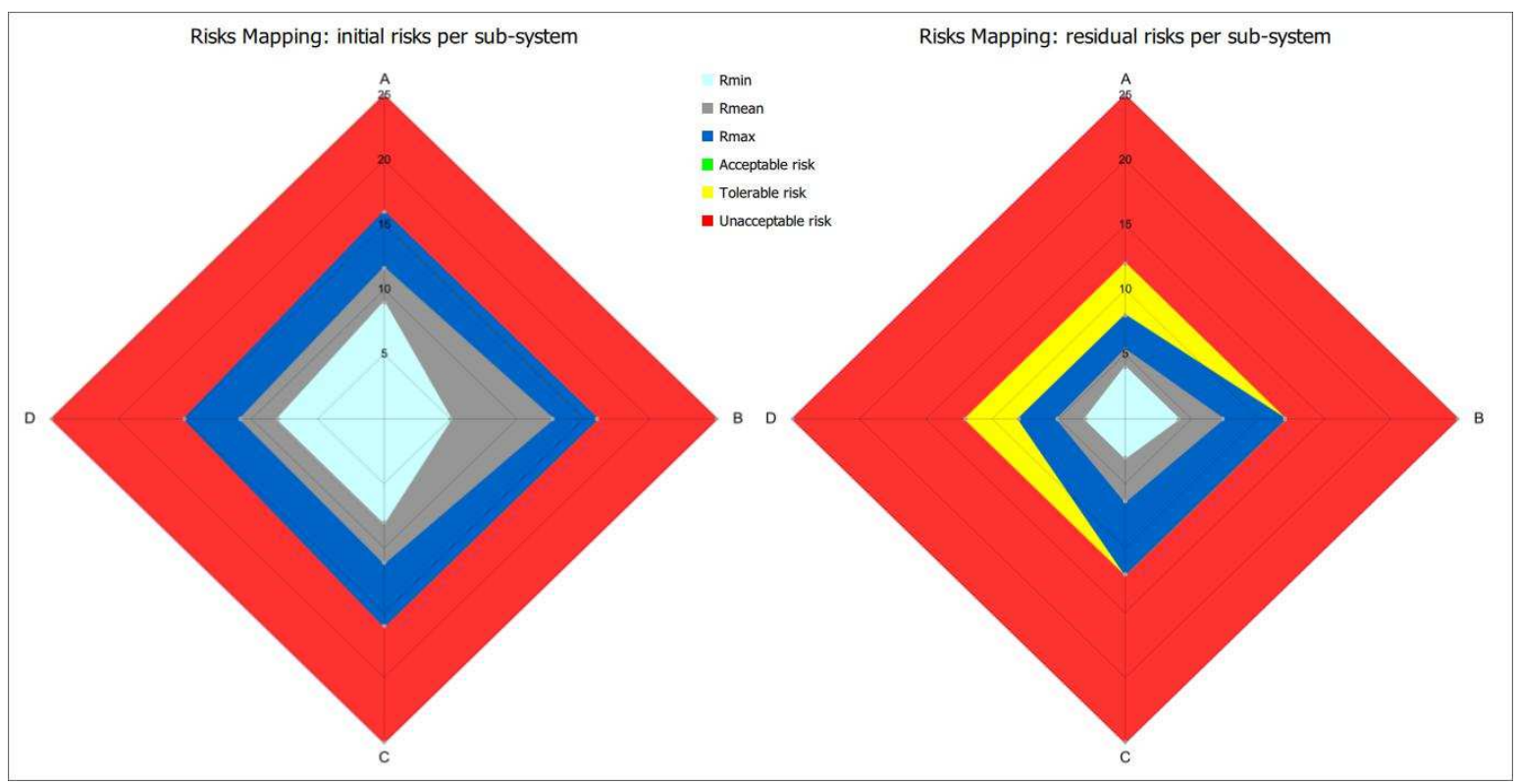

Fig. 7. Kiviat diagram for initial and residual risks per project phase

According to the left-sided Kiviat diagram in Fig.7, we notice that the initial risks that emerge from the four phases of the project have maximum risk indexes with $\mathrm{C} 3$ criticality. Thus, all the four phases should be a priority for project managers in order to avoid serious consequences. In fact, among the four phases, only the initial risks arising from the preparation phase (B) have an average risk index with C3 criticality. This result confirms the vulnerability of this phase, which requires more importance than the other three phases. 
After the implementation of the initial risk reduction actions (right-sided Kiviat diagram in Fig.7), we can make the following remarks:

- None of the residual risk indexes (minimum, average or maximum) from the four phases has a C3 cirticality. Thus, the risk reduction actions implemented have succeeded in bringing all the risk indexes to criticality levels $\mathrm{C} 2$ or $\mathrm{C} 1$. This result proves the effectiveness of the applied actions.

-The residual risks arising from the preparation (B) and construction (C) phases have a residual average risk index of $\mathrm{C} 2$ criticality. Consequently, the residual risks arising from these phases are tolerable under control and require control actions, such as insurance. This observation leads us to stress the high vulnerability of the preparation phase to generic hazards.

\subsection{List of major risks and recommendations}

The GRA method allows us to determine the list of top risks. We will explain in details in this sub-section the main causes of the top risks and the convenient strategies and actions that we propose to reduce these risks.

The list of top risks identified in the present study is in line with many studies dealing with barriers to CSP investment in the MENA region. In fact, previous studies have pointed out the importance of financing barriers (Lilliestam et al., 2012), the bureaucracy and corruption (Komendantova et al., 2011), and the regulatory risk which can delay obtaining a permission (Komendantova et al., 2012). However, we find that the risk of conflicts with local residents is a serious risk that should be taken into account by developers. This result is in contrast with the analysis of Hanger et al. (2016) which shows that community acceptance is almost universal for the case of the CSP plant Noor in Morocco.

Concerning the risk of failure to achieve the expected performance because of the use of tower technology with dry cooling, this result is in contrast with the analysis of Trabelsi et al. (2016) which proves that due to the high DNI in Southern Tunisia, CSP plants with dry cooling are technically and economically competitive with the wet cooled CSP plants. Nevertheless, this research deals with parabolic trough technology and not tower technology which is used in our case study.

The major risks that can affect the CSP plant, their causes and the main actions that we propose to reduce these risks are explained as follows: 


\section{- The risk of not obtaining a permission to build a CSP plant}

This risk results from the absence of a legal framework for the export of electricity produced from RE, in Tunisia, and the complexity of approval procedures. Moreover, the political instability since the revolution and the lack of visibility in the medium and long-term are all factors that have aggravated the situation.

In order to eliminate this legal barrier and have a suitable legal framework for this project, the project managers have initiated, since 2010, discussions with the government officials in order to develop a new regulation suitable for this project. Fortunately, after many years of waiting, a new law which authorizes the export of green electricity was approved in 2015 .

\section{- The risk of non compliance with deadlines}

These delays can be caused mainly by bureaucracy, corruption, long and complicated administrative procedures, administrative inefficiency, delays in signing contracts, and a poor estimation of the processing time.

Moreover, uncertainty and unexpected events are linked to any large scale project so, there is always the possibility of delays. In Tunisia, this risk is more frequent due to bureaucracy and corruption, therefore, the project managers should set realistic deadlines taking into account the Tunisian context. In addition, many delays are predictable and quite common to all RE projects in the developing countries so, they can be expected and integrated into the schedule in advance. Finally, the project managers should be very proactive and have a great experience concerning large scale projects in Tunisia.

\section{- The risk of failure to achieve the expected performance}

This risk can be caused by the use of tower technology that is not widely used in the MENA region, as is the case for the parabolic trough technology. It can also be caused by the use of dry cooling that has not been widely experienced yet. In addition, there is a lack of experience feedback in Tunisia, since it is the first CSP project of a large size.

In order to reduce this risk, feedback from similar projects will be very useful. In fact, the CSP tower technology is used today in several countries, such as India, Spain, South Africa and the USA. Recently, the project Noor III using the same technology (CSP tower with molten salt storage) has been successfully implemented, which will help us to have a very interesting feedback from a country very similar to Tunisia. The conclusion of insurance 
contracts, the use of internationally renowned suppliers and the use of preventive and regular maintenance are also highly recommended.

\section{- The risk of insufficient access to capital}

This risk is caused by the high cost of capital, the short pay-back periods of credits and the lack of private sector participation. This risk is very common in many developing countries and can be reduced by the following measures:

-Strengthening the public private partnerships (PPP) to finance large CSP projects. In fact, PPP are an interesting solution for Tunisia, which suffers from serious budgetary constraints and does not have the means either to cover the financial losses of public enterprises or to invest in the renovation and extension of its electricity network. To ensure the success of PPP, Tunisia must put in place a strong business climate that attracts investors. This requires reducing administrative procedures to access markets, establishing a solid and stable financial system and appealing to international assistance funds, such as the Public-Private Infrastructure Advisory Facility (PPIAF).

-The implementation of feed-in tariff mechanism. This mechanism was very effective, in many countries, both in stimulating installed capacity and in developing local industry. In fact, tariffs should be set at a level that ensures the cost-effectiveness of RE projects. As a result, the market risk incurred by the project developer is inexistent and the profitability of the project depends essentially on cost control and attainment of maximum performance.

-Requesting the assistance and the support from international financial institutions and development agencies to reduce the costs of financing this project. In fact, they generally offer low-rate loans for longer periods compared to commercial banks.

\section{- The risk of conflicts with local residents}

This risk can be caused by the opposition to the implementation of the CSP plant and nimbyism. In order to reduce this risk, we propose the following measures:

-The use of participatory approaches which have several advantages. First of all, the participation of the various actors in the decision-making process gives some legitimacy and transparency to this decision and thus reduces the risk of non-acceptance of the decision by these same actors. In addition, the participatory approach allows decision-makers to have access to a very interesting database that concerns the preferences and expectations of different actors, especially, in terms of local employment and development of the region. In 
fact, it is essential to organize public consultations to collect the different issues and the main occupations of the local population and discuss these concerns with stakeholders in order to satisfy the expectations of the citizens.

-The creation of local employment is recommended. Local employees must be privileged, especially, during the construction phase which requires a high number of low-skilled workers. Indeed, the project can increase the activity of small and medium-sized local firms for the supply of the materials and the necessary equipments for the construction work, the housing and the restoration of the workers. Hence, it is also highly recommended to set up an employment commission to study the best way to promote local employment and organize short-term training for young graduates in order to acquire new skills and qualifications required for this project, while trying to achieve parity between the employment of women and men.

-The communication about the RE sector must be adequate and effective. Indeed, citizens and all the actors involved in the RE sector should have the necessary and up-to-date information on the objectives of the government, the means implemented, the regulatory and legal framework, and the achievements made. In order to ensure such communication, an updated website, discussion forums, and workshops at national and regional levels should be set up.

\section{Conclusion}

The application of the GRA method for the case of a CSP plant in Tunisia helped us to analyze in depth, the types of hazards that most affect the project, the phase of the project that is the most vulnerable to hazards, and the major risks that hinder its implementation.

The results of the analysis by generic hazard type show that the project is very exposed to political, physical-chemical, financial, and strategic hazards. The political hazard generates $30 \%$ of all hazardous situations, which means that the political situation in Tunisia has a negative influence on the realization of this project. The Kiviat diagram shows that, even though the legal hazard generates only 2 hazardous situations, it should be taken very seriously by investors since risks resulting from this hazard have the minimum, medium and maximum risk indexes of $\mathrm{C} 3$ criticality (unacceptable).

With regard to the analysis per project phase (feasibility study, preparation, construction, and operation), the two phases of preparation and operation contain the highest shares of hazardous situations, which makes them more exposed to the 14 generic hazards than the feasibility study and the construction phases. The Kiviat diagram demonstrates that, among 
the four phases, only the initial risks arising from the preparation phase have an average risk index of $\mathrm{C} 3$ criticality. This further proves the vulnerability of this phase, which requires more attention than the other three phases. In fact, this phase encompasses all administrative procedures relating to authorizations for the construction and connection to the electricity grid and may even last for many years. In Tunisia, the case is even more serious as the project has been blocked in this phase for more than 6 years.

In addition to that, the GRA enabled us to identify the list of major risks that may affect the CSP project which are: the risk of not obtaining permission to build the CSP plant, the risk of non compliance with the deadline, the risk of failure to achieve the expected performance, the risk of insufficient access to capital, and the risk of conflicts with local residents. Then, their causes and the main actions proposed to reduce them are explained. In fact, in order to reduce these investment risks, we have proposed many measures and strategies, such as the strengthening of the public private partnership to finance this project, the use of participatory approaches, the creation of local employment, and the recourse to international financial institutions and development agencies to reduce the costs of the project.

The list of top risks identified in the present study is in line with many studies dealing with barriers to CSP investment in the MENA region which pointed out the importance of financing barriers, the bureaucracy and corruption, and the regulatory risk (Komendantova et al., 2011, 2012; Lilliestam et al., 2012).

However, we found that the risk of conflicts with local residents is a major risk that should be taken into account. This result is in contrast with the analysis of Hanger et al. (2016). We can explain this difference by the fact that the electricity produced by the CSP plant studied in this paper is intended for exports while the other cases deal with CSP plants producing electricity to strengthen the national grid and satisfy the national demand. In fact, producing electricity to be totally exported is seen by many citizens as an exploitation of national energy resources by the countries of the North.

We also found that the risk of failure to achieve the expected performance because of the use of tower technology with dry cooling is a major risk, which is in contrast with the result found by Trabelsi et al. (2016). This contrast can be explained by the fact that these authors treated parabolic trough technology, which is a more mature and used technology than tower technology that will be used for the CSP studied in this paper. 
It should be noted that, over the past few years, Tunisia has begun many structural changes in the RE sector in order to de-risk and promote this sector. In fact, a new law for RE was approved in 2015. This law authorizes the exportation of electricity from RE and encourages citizens and local communities to produce green electricity. However, the distribution of electricity remains under the monopoly of STEG.

Furthermore, in order to create a favorable climate for PPP, a new law for PPP was adopted in 2015. This law is supposed to facilitate, clarify and organize PPP procedures and, above all, ensure an efficient management of the contractual risks that are frequent in this complex type of contracts. Therefore, the objective of this law is to provide a unified legislative and institutional framework that encourages private investors.

Even though Tunisia has made some progress, mainly in terms of legal framework, there are still several challenges and obstacles that slow down the development of CSP technology and $\mathrm{RE}$ in general as it is demonstrated by the present analysis.

However, like any research work, this study has limitations. Indeed, it is limited to a semiquantitative study (since there are the severity and likelihood indexes). In addition, it remains general with no focus on financial risks, which are among the most serious and worrying risks for investors in the RE sector.

Although, it is very important to use the GRA method at the beginning of a project to give an overall view of the risks that may occur, this is not enough since the GRA should also accompany the whole life of the project and therefore must be revised and completed as the project progresses. The other disadvantage of this method lies in the subjectivity in risk assessment. Indeed, the estimation of the likelihood of occurrence and the severity of consequences in order to deduce the criticality remains a very subjective process.

In addition, this case study cannot be generalized to all CSP projects in Tunisia, since each CSP project remains unique and different and has specific risks, but this study remains very important and gives a general and an approximate idea of the barriers that may be encountered by future CSP investors in Tunisia.

In order to overcome these limitations, in future research studies, it will be highly recommended to complete this research by the quantitative AGR method (AGRq). The use of this method will be very interesting in the case of availability of probabilities related to risk factors. The main contribution of this method is the possibility of having a probabilistic representation of the risks and a financial evaluation of the cost/risk ratios. 


\section{Acknowledgments}

We are especially grateful to Prof. Alain Desroches from Ecole Centrale Paris who generously shared with us his knowledge on risk management and Global Risk Analysis method as well as to Dr. Sébastien Delmotte from MAD Environnement (www.madenvironnement.com) for his helpful suggestions and practical advice about the use of the SATATCART GRA software.

\section{Appendixes. Supplementary material}

\section{References}

Amato, A., Compare, M., Gallisto, M., Maccari, A., Paganelli, M., Zio, E., 2011. Business interruption and loss of assets risk assessment in support of the design of an innovative concentrating solar power plant. Renew. Energy 36, 1558-1567.

Arentsen, M., Kemp, R., Luiten, E., 2002. Technological change and innovation for climate protection: The governance challenge, in: Kok, M., Vermeulen, W., Faaij, A., De Jager, D. (Eds.), Global Warming and Social Innovation: The Challenge of a Climate Neutral Society. Earthscan, London, pp. 59-82.

Arthur, B., 1989. Competing technologies: Increasing returns and lock-in by historical events. Econ. J. 99, 116-131.

Arthur, B., 1994. Increasing Returns and Path Dependence in the Economy, first ed. University of Michigan Press, Ann Arbor.

Astolfi, M., Binotti, M., Mazzola, S., Zanellato, L., Manzolini, G., 2017. Heliostat aiming point optimization for external tower receiver. Sol. Energy 157, 1114-1129.

Ayres, R.U., 1991. Evolutionary economics and environmental imperatives. Struct. Chang. Econ. Dyn. 2, 255-273.

Balghouthi, M., Trabelsi, S.E., Ben Amara, M., Bel Hadjali, A., Guizani, A., 2016. Potential of concentrating solar power (CSP) technology in Tunisia and the possibility of interconnection with Europe. Renew. Sustain. Energy Rev. 56, 1227-1248.

Belgasim, B., Aldali, Y., Abdunnabi, M.J.R., Hashem, G., Hossin, K., 2018. The potential of concentrating solar power (CSP) for electricity generation in Libya. Renew. Sustain. Energy Rev. 90, 1-15. 
Böhringer, C., Cuntz, A., Harhoff, D., Asane-Otoo, E., 2017. The impact of the German feedin tariff scheme on innovation: Evidence based on patent filings in renewable energy technologies. Energy Econ. 67, 545-553.

Brand, B., Stambouli, A.B., Zejli, D., 2012. The value of dispatchability of CSP plants in the electricity systems of Morocco and Algeria. Energy Policy 47, 321-331.

Cowan, R., 1990. Nuclear power reactors: A study in technological lock-in. J. Econ. Hist. 50, $541-567$.

David, P.A., 1985. Clio and the economics of QWERTY. Am. Econ. Rev. 75, 332-337.

Davis, S.J., Caldeira, K., Matthews, H.D., 2010. Future $\mathrm{CO}_{2}$ emissions and climate change from existing energy infrastructure. Science 329, 1330-1333.

del Río, P., Peñasco, C., Mir-Artigues, P., 2018. An overview of drivers and barriers to concentrated solar power in the European Union. Renew. Sustain. Energy Rev. 81, 1019-1029.

Desroches, A., 2013. Le management des risques par l'analyse globale des risques. Transfus. Clin. Biol. 20, 198-210.

Desroches, A., Aguini, N., Dadoun, M., Delmotte, S., 2016. L'Analyse Globale des Risques_ Principes et Pratiques, deuxième ed. Hermès Science Publications, Paris.

Dosi, G., 1982. Technological paradigms and technological trajectories: A suggested interpretation of the determinants and directions of technical change. Res. Policy 11, $147-162$.

Elum, Z.A., Momodu, S., 2017. Climate change mitigation and renewable energy for sustainable development in Nigeria: A discourse approach. Renew. Sustain. Energy Rev. 76, 72-80.

Fragkos, P., Paroussos, L., 2018. Employment creation in EU related to renewables expansion. Appl. Energy 230, 935-945.

Freeman, C., Soete, L., 1997. The Economics of Industrial Innovation, third ed. MIT Press, Cambridge.

Frisari, G., Stadelmann, M., 2015. De-risking concentrated solar power in emerging markets: The role of policies and international finance institutions. Energy Policy 82, 12-22. 
Gabriel, C-A., 2016. What is challenging renewable energy entrepreneurs in developing countries? Renew. Sustain. Energy Rev. 64, 362-371.

Goh, T., Ang, B.W., 2018. Quantifying CO2 emission reductions from renewables and nuclear energy - Some paradoxes. Energy Policy 113, 651-662.

González, M.O.A., Gonçalves, J.S., Vasconcelos, R.M., 2017. Sustainable development: Case study in the implementation of renewable energy in Brazil. J. Clean. Prod. 142, 461475 .

Haas, J., Palma-Behnke, R., Valencia, F., Araya, P., Díaz-Ferrán, G., Telsnig, T., Eltrop, L., Díaz, M., Püschel, S., Grandel, M., Román, R., Jiménez-Estévez, G., 2018. Sunset or sunrise? Understanding the barriers and options for the massive deployment of solar technologies in Chile. Energy Policy 112, 399-414.

Hanger, S., Komendantova, N., Schinke, B., Zejli, D., Ihlal, A., Patt, A., 2016. Community acceptance of large-scale solar energy installations in developing countries: Evidence from Morocco. Energy Res. Soc. Sci. 14, 80-89.

Hustveit, M., Frogner, J.S., Fleten, S-E., 2017.Tradable green certificates for renewable support: The role of expectations and uncertainty. Energy 141, 1717-1727.

IEA, 2007. World Energy Outlook 2007, China and India Insights. International Energy Agency, Paris.

IEA, 2010. Technology Roadmap-Concentrating Solar Power. International Energy Agency. https://www.iea.org/publications/freepublications/publication/csp_roadmap.pdf (accessed 13 February 2014).

IEA, 2011. World Energy Outlook 2011. International Energy Agency. www.iea.org/publications/freepublications/publication/WEO2011_WEB.pdf (accessed 7 January 2012).

IEA, 2014. Technology Roadmap: Solar Thermal Electricity. International Energy Agency. https://www.iea.org/publications/freepublications/publication/TechnologyRoadmapSola rThermalElectricity_2014edition.pdf (accessed 3 October 2018).

IPCC, 2007. Climate Change 2007: Impacts, Adaptation and Vulnerability. Contribution of Working Group II to the Fourth Assessment Report of the Intergovernmental Panel on Climate Change. Intergovernmental Panel on Climate Change, Cambridge, United Kingdom and New York, USA. 
IRENA Resource, 2018. International Renewable Energy Agency Resource. http://resourceirena.irena.org/gateway/dashboard/?topic=4\&subTopic=16 (accessed 19 September 2018).

IRENA, 2018. Renewable Power Generation Costs in 2017. International Renewable Energy Agency, Abu Dhabi.

Joskow, P.L., 2011. Comparing the costs of intermittent and dispatchable electricity generating technologies. Am. Econ. Rev. 101, 238-241.

Kemp, R., 1994. Technology and the transition to environmental sustainability: The problem of technological regime shifts. Futures 26, 1023-1046.

Komendantova, N., Patt, A., Williges, K., 2011. Solar power investment in North Africa: Reducing perceived risks. Renew. Sustain. Energy Rev. 15, 4829-4835.

Komendantova, N., Patt, A., Barras, L., Battaglini, A., 2012. Perception of risks in renewable energy projects: The case of concentrated solar power in North Africa. Energy Policy 40, 103-109.

Kost, C., Pfluger, B., Eichhammer, W., Ragwitz, M., 2011. Fruitful symbiosis: Why an export bundled with wind energy is the most feasible option for North African concentrated solar power. Energy Policy 39, 7136-7145.

Kost, C., Engelken, M., Schlegl, T., 2012. Value generation of future CSP projects in North Africa. Energy Policy 46, 88-99.

Labordena, M., Patt, A., Bazilian, M., Howells, M., Lilliestam, J., 2017. Impact of political and economic barriers for concentrating solar power in Sub-Saharan Africa. Energy Policy 102, 52-72.

Liebowitz, S.J., Margolis, S.E., 1995. Path dependence, lock-in and history. J. L. Econ. \& Org. 11, 205-226.

Lilliestam, J., Bielicki, J. M., Patt, A.G., 2012. Comparing carbon capture and storage (CCS) with concentrating solar power (CSP): Potentials, costs, risks, and barriers. Energy Policy 47, 447-455.

Lilliestam, J., Barradi, T., Caldés, N., Gomez, M., Hanger, S., Kern, J., Komendantova, N., Mehos, M., Hong, W.M., Wang, Z., Patt, A., 2018. Policies to keep and expand the 
option of concentrating solar power for dispatchable renewable electricity. Energy Policy 116, 193-197.

Mahia, R., de Arce, R., Medina, E., 2014. Assessing the future of a CSP industry in Morocco. Energy Policy 69, 586-597.

Mattauch, L., Creutzig, F., Edenhofer, O., 2015. Avoiding carbon lock-in: Policy options for advancing structural change. Econ. Model. 50, 49-63.

Mazeron, R., Aguini, N., Rivin, E., Baudré, A., Bour, M-S., Dumas, I., Hubert, F., Lopes, S., Desroches, A., Deutsch, E., Lefkopoulos, D., Bourhis, J., 2014. Improving safety in radiotherapy: the implementation of the Global Risk Analysis method. Radiother. Oncol. 112, 205-211.

Medina, E., de Arce, R., Mahía, R., 2015. Barriers to the investment in the Concentrated Solar Power sector in Morocco: A foresight approach using the Cross Impact Analysis for a large number of events. Futures 71, 36-56.

Mekhilef, S., Saidur, R., Safari, A., 2011. A review on solar energy use in industries. Renew. Sustain. Energy Rev. 15, 1777-1790.

Menanteau, P., Finon, D., Lamy, M-L., 2003. Prices versus Quantities: choosing policies for promoting the development of renewable energy. Energy Policy 31, 799-812.

Mezher, T., Dawelbait, G., Abbas, Z., 2012. Renewable energy policy options for Abu Dhabi: Drivers and barriers. Energy Policy 42, 315-328.

Nelson, R.R., Winter, S.G., 1977. In search of useful theory of innovation. Res. Policy 6, 3676.

Nock, D., Baker, E., 2017. Unintended consequences of Northern Ireland's renewable obligation policy. The Electricity Journal 30, 47-54.

OECD, 2012. Linking Renewable Energy to Rural Development, OECD Publishing. www.oecd.org/regional/regional-policy/Renewable-rural-energy-summary.pdf (accessed 25 November 2018).

Omri, E., Chtourou, N., Bazin, D., 2015a. Rethinking the green recovery through renewable energy expansion. Int. J. Sustain. Dev. 18, 59-76. 
Omri, E., Chtourou, N., Bazin, D., 2015b. Solar thermal energy for sustainable development in Tunisia: The case of the PROSOL project. Renew. Sustain. Energy Rev. 41, 13121323.

Otieno, G.A., Loosen, A.E., 2016. An analysis of key environmental and social risks in the development of concentrated solar power projects. AIP Conference Proceedings 1734, 160012.

Painuly, J.P., 2001. Barriers to renewable energy penetration: a framework for analysis. Renew. Energy 24, 73-89.

Perkins, R., 2003. Technological Lock-in. International Society for Ecological Economics, Internet Encyclopedia of Ecological Economics. http://isecoeco.org/pdf/techlkin.pdf (accessed 23 July 2015).

Pfenninger, S., Gauche, P., Lilliestam, J., Damerau, K., Wagner, F., Patt, A., 2014. Potential for concentrating solar power to provide baseload and dispatchable power. Nat. Clim. Change 4, 689-692.

Pietzcker, R.C., Stetter, D., Manger, S., Luderer, G., 2014. Using the sun to decarbonize the power sector: the economic potential of photovoltaics and concentrating solar power. Appl. Energy 135, 704-720.

Pinkse, J., Buuse, D.V.D., 2012. The development and commercialization of solar PV technology in the oil industry. Energy Policy 40, 11-20.

Poullikkas, A., Hadjipaschalis, I., Kourtis, G., 2010. The cost of integration of parabolic trough CSP plants in isolated Mediterranean power systems. Renew. Sustain. Energy Rev. 14, 1469-1476.

REN21, 2018. Renewables 2018: Global Status Report. Renewable Energy Policy Network for the $21^{\text {st }}$ Century. http://www.ren21.net/wp-content/uploads/2018/06/178652_GSR2018_FullReport_web_final_.pdf (accessed 15 September 2018).

Rip, A., Kemp, R., 1998. Technological change, in: Rayner, S., Malone, E. (Eds.), Human Choice and Climate Change-Volume 2: Resources and Technology. Battelle Press, Columbus, pp. 327-399.

Schinko, T., Komendantova, N., 2016. De-risking investment into concentrated solar power in North Africa: Impacts on the costs of electricity generation. Renew. Energy 92, 262272. 
Schmidt, R.C., Marschinski, R., 2009. A model of technological breakthrough in the renewable energy sector. Ecol. Econ. 69, 435-444.

Sindhu, S.P., Nehra, V., Luthra, S., 2016. Recognition and prioritization of challenges in growth of solar energy using analytical hierarchy process: Indian outlook. Energy 100, 332-348.

Stadelmann, M., Frisari, G., Konda, C., 2014. The Role of Public Finance in CSP: Case Study Rajasthan Sun Technique. Climate Policy Initiative, India. http://climatepolicyinitiative.org/wp-content/uploads/2014/03/SGG-Case-Study-The-

Role-of-Public-Finance-in-CSP-Rajasthan-Sun-Technique-India.pdf (accessed 7 April 2016).

Trabelsi, S.E., Chargui, R., Qoaider, L., Liqreina, A., Guizani, A.A., 2016. Techno-economic performance of concentrating solar power plants under the climatic conditions of the southern region of Tunisia. Energy Convers. Manag. 119, 203-214.

Trieb, F., Müller-Steinhagen, H., Kern, J., 2011. Financing concentrating solar power in the Middle East and North Africa—subsidy or investment? Energy Policy 39, 307-317.

Trieb, F., Schillings, C., Pregger, T., O’Sullivan, M., 2012. Solar electricity imports from the Middle East and North Africa to Europe. Energy Policy 42, 341-353.

Trieb, F., Fichter, T., Moser, M., 2014. Concentrating solar power in a sustainable future electricity mix. Sustain. Sci. 9, 47-60.

Unruh, G.C., 2000. Understanding carbon lock-in. Energy Policy 28, 817-830.

Unruh, G.C., 2002. Escaping carbon lock-in. Energy Policy 30, 317-325.

Viebahn, P., Lechon, Y., Trieb, F., 2011. The potential role of concentrated solar power (CSP) in Africa and Europe: a dynamic assessment of technology development, cost development and life cycle inventories until 2050. Energy Policy 39, 4420-4430.

Wiesinger, F., Sutter, F., Wolfertstetter, F., Hanrieder, N., Fernández-García, A., Pitz-Paal, R., Schmücker, M., 2018. Assessment of the erosion risk of sandstorms on solar energy technology at two sites in Morocco. Sol. Energy 162, 217-228.

Williges, K., Lilliestam, J., Patt, A., 2010. Making concentrated solar power competitive with coal: the costs of a European feed-in tariff. Energy Policy 38, 3089-3097. 
Xin-gang, Z., Ling-zhi, R., Yu-zhuo, Z., Guan, W., 2018. Evolutionary game analysis on the behavior strategies of power producers in renewable portfolio standard. Energy 162, $505-516$.

Xu, X., Vignarooban, K., Xu, B., Hsu, K., Kannan, A.M., 2016. Prospects and problems of concentrating solar power technologies for power generation in the desert regions. Renew. Sustain. Energy Rev. 53, 1106-1131.

Zongxian, Z., Yang, W., Xiaofei, S., Ming, Z., 2012. Risk assessment of concentrating solar power based on fuzzy comprehensive evaluation. Syst. Eng. Procedia 4, 99-106. 


\section{Appendix A. The CSP project depicted in steps, phases and sub-phases.}

\begin{tabular}{|c|c|c|}
\hline Steps & Phases & Sub-phases \\
\hline \multirow[t]{8}{*}{ Feasibility study (A) } & Site identification & Determining available sites \\
\hline & \multirow{2}{*}{ Resource estimation } & Estimation of solar radiation \\
\hline & & Estimation of the electricity generated \\
\hline & Estimation of the possibility of connection & $\begin{array}{l}\text { Estimation of power that can be connected to the grid } \\
\text { Determining interconnection costs }\end{array}$ \\
\hline & \multirow[t]{3}{*}{ Economic study } & Project cost estimate \\
\hline & & Estimation of potential demand \\
\hline & & Estimation of the project profitability \\
\hline & Environmental study & Study of the geological characteristics of the site \\
\hline \multirow[t]{25}{*}{ Preparation (B) } & \multirow[t]{2}{*}{ Technical study } & Solar resource characterization \\
\hline & & $\begin{array}{l}\text { Fixing the technical characteristics of the mirrors used } \\
\text { Determining the necessary equipments }\end{array}$ \\
\hline & \multirow[t]{2}{*}{ Environmental and social study } & Study of environmental impacts \\
\hline & & Study of social impacts \\
\hline & \multirow[t]{4}{*}{ Selection of partners } & Identification of partners \\
\hline & & Sharing roles \\
\hline & & Coordination between partners \\
\hline & & Creation of a project team \\
\hline & \multirow[t]{5}{*}{ Elaboration of a financing plan } & Determination of the overall cost of the project \\
\hline & & Identification of available financial assistance \\
\hline & & Determining the amount of potential subsidies \\
\hline & & Determining the necessary loans \\
\hline & & Fixing the repayment terms \\
\hline & \multirow{5}{*}{$\begin{array}{l}\text { Completing the necessary administrative } \\
\text { procedures }\end{array}$} & Real estate negotiation \\
\hline & & Building permit application \\
\hline & & Choosing the legal structure of the project-carrying unit \\
\hline & & Signing contracts \\
\hline & & Tariff agreement \\
\hline & \multirow[t]{4}{*}{ Determining an action plan } & Organization of working meetings \\
\hline & & Identification of project duration \\
\hline & & Determination of construction phases \\
\hline & & Determination of start up and completion dates \\
\hline & \multirow{3}{*}{$\begin{array}{l}\text { Mobilization of required human resources } \\
\text { Communication }\end{array}$} & Organization of job interviews \\
\hline & & Communication with the local community \\
\hline & & Project media coverage \\
\hline \multirow[t]{12}{*}{ Construction (C) } & \multirow[t]{9}{*}{ Installation } & Ensuring access roads to the site \\
\hline & & Site development \\
\hline & & Site water supply \\
\hline & & Acquiring the necessary equipments \\
\hline & & Solar field's construction \\
\hline & & Generator construction \\
\hline & & Construction of the energy evacuation device \\
\hline & & Construction of the storage structure \\
\hline & & Installation of associated infrastructure \\
\hline & \multicolumn{2}{|c|}{ Preparing connection to the national electricity grid } \\
\hline & \multicolumn{2}{|c|}{ Preparing the necessary infrastructure } \\
\hline & \multicolumn{2}{|c|}{ Implementation of HVDC lines between Tunisia and Italy } \\
\hline \multirow[t]{9}{*}{ Operation (D) } & Generation of electricity & Collection of solar radiation using mirrors \\
\hline & & Concentration of the sunlight on a receiver \\
\hline & & Heating a heat transfer fluid \\
\hline & & Production of heat in the form of steam \\
\hline & & Steam drives turbine/generator to produce electricity \\
\hline & & Storage of heat in molten salt \\
\hline & Connection to the national electricity grid & \\
\hline & Export of electricity to Italy & \\
\hline & Loan repayments & \\
\hline
\end{tabular}


Appendix B. The hazard mapping.

\begin{tabular}{|c|c|c|c|}
\hline Generic hazards & Abbreviation & Specific hazards & Hazardous events \\
\hline Political & POL & International & $\begin{array}{l}\text { No more world bank support for CSP projects } \\
\text { Decrease in fossil fuel prices } \\
\text { Setting grade by rating agencies } \\
\text { Non-compliance with the European regulatory } \\
\text { framework for electricity } \\
\text { Bad choice of installation site } \\
\text { Complexity of bureaucratic procedures } \\
\text { Corruption } \\
\text { Bad governance of public enterprises } \\
\text { Political instability } \\
\text { Lack of guarantees from the government } \\
\text { Revolution } \\
\text { Political uncertainty } \\
\text { Increase of subsidies for fossil fuels } \\
\text { Recurrence of strikes and sit-ins in Tunisia } \\
\text { Recurrent changes in government } \\
\text { Uncertain government policies } \\
\text { Lack of transparency } \\
\text { Lack of infrastructure }\end{array}$ \\
\hline Environment & ENV & Natural & $\begin{array}{l}\text { Sandstorm } \\
\text { The depth of the Mediterranean sea } \\
\text { Strong wind } \\
\text { Erosion } \\
\text { Earthquake } \\
\text { Lightning }\end{array}$ \\
\hline Insecurity & INS & $\begin{array}{l}\text { Computer } \\
\text { Material }\end{array}$ & $\begin{array}{l}\text { Computer virus } \\
\text { Identity theft } \\
\text { Terrorism } \\
\text { Unavailability of equipments }\end{array}$ \\
\hline Image & IMA & Media & $\begin{array}{l}\text { Lack of media support for the project } \\
\text { Lack of awareness of the benefits of RE } \\
\text { Unfavorable testimonials on social media }\end{array}$ \\
\hline Management & MAN & (n) & $\begin{array}{l}\text { Bad organization of work } \\
\text { Insufficient site observation period } \\
\text { Unrealistic project implementation schedule } \\
\text { Underestimated time of file's processing } \\
\text { Delay in construction } \\
\text { Unavailability of project managers } \\
\text { Technical consultants not experienced in the } \\
\text { field of large projects } \\
\text { Insufficient staff training } \\
\text { Poor proficiency in English } \\
\text { Poor proficiency in Arabic } \\
\text { Non-recruitment of local staff } \\
\text { Poor knowledge of the activity } \\
\text { Failure to follow safety instructions } \\
\text { Uncomfortable working conditions } \\
\text { Bad decision } \\
\text { Overwork } \\
\text { Stress }\end{array}$ \\
\hline Strategic & STR & Cooperation & $\begin{array}{l}\text { Poor cooperation with the African Development } \\
\text { Bank } \\
\text { Poor cooperation with the energy transition fund }\end{array}$ \\
\hline
\end{tabular}




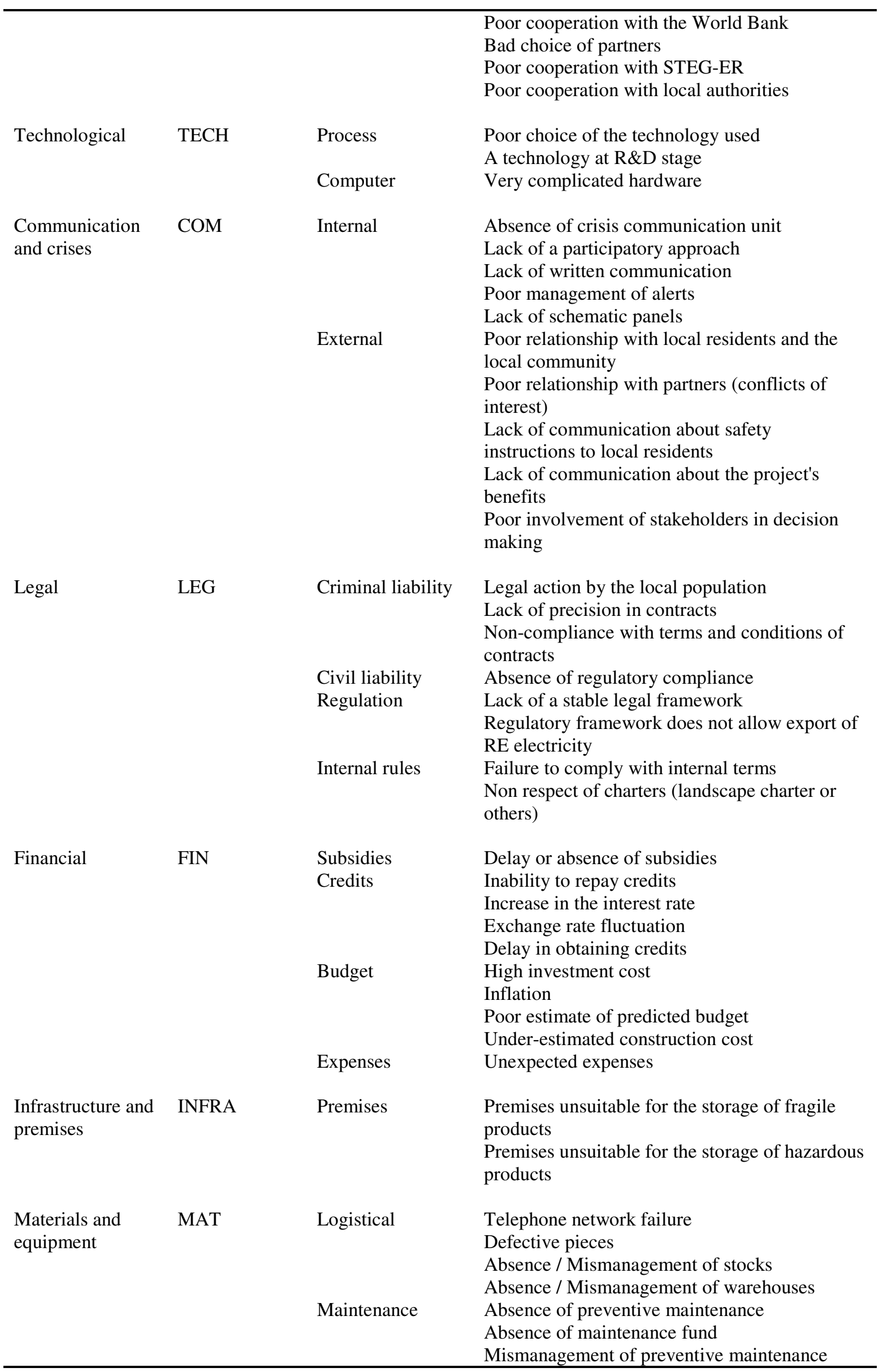




\begin{tabular}{|c|c|c|c|}
\hline \multirow{9}{*}{$\begin{array}{l}\text { Information } \\
\text { system }\end{array}$} & \multirow[t]{9}{*}{ IS } & Network & Internet connection cut \\
\hline & & Data & Incomplete or wrong data \\
\hline & & & Data classification error \\
\hline & & & Loss of files \\
\hline & & & Poor experience feedback \\
\hline & & & Unavailability of data \\
\hline & & & Failure to anonymize data \\
\hline & & System & System does not respond to the situation reality \\
\hline & & Software & Very complicated software \\
\hline \multirow[t]{18}{*}{ physical/chemical } & \multirow[t]{18}{*}{$\mathrm{PCH}$} & Electrical & Overvoltage \\
\hline & & & Power cut \\
\hline & & & $\begin{array}{l}\text { Insufficient electricity } \\
\text { Noise }\end{array}$ \\
\hline & & Mechanical & $\begin{array}{l}\text { Noise } \\
\text { Fall }\end{array}$ \\
\hline & & & Explosion \\
\hline & & & Vibration \\
\hline & & Thermal & Fire \\
\hline & & & Hot spot \\
\hline & & Hydraulic & Overpressure \\
\hline & & & Leakage \\
\hline & & & Breakage \\
\hline & & Chemical & Pollution \\
\hline & & & Corrosion \\
\hline & & & Chemical reaction \\
\hline & & & Explosion \\
\hline & & & Oxidation \\
\hline & & & Flammability \\
\hline & & Biological & Toxicity \\
\hline
\end{tabular}




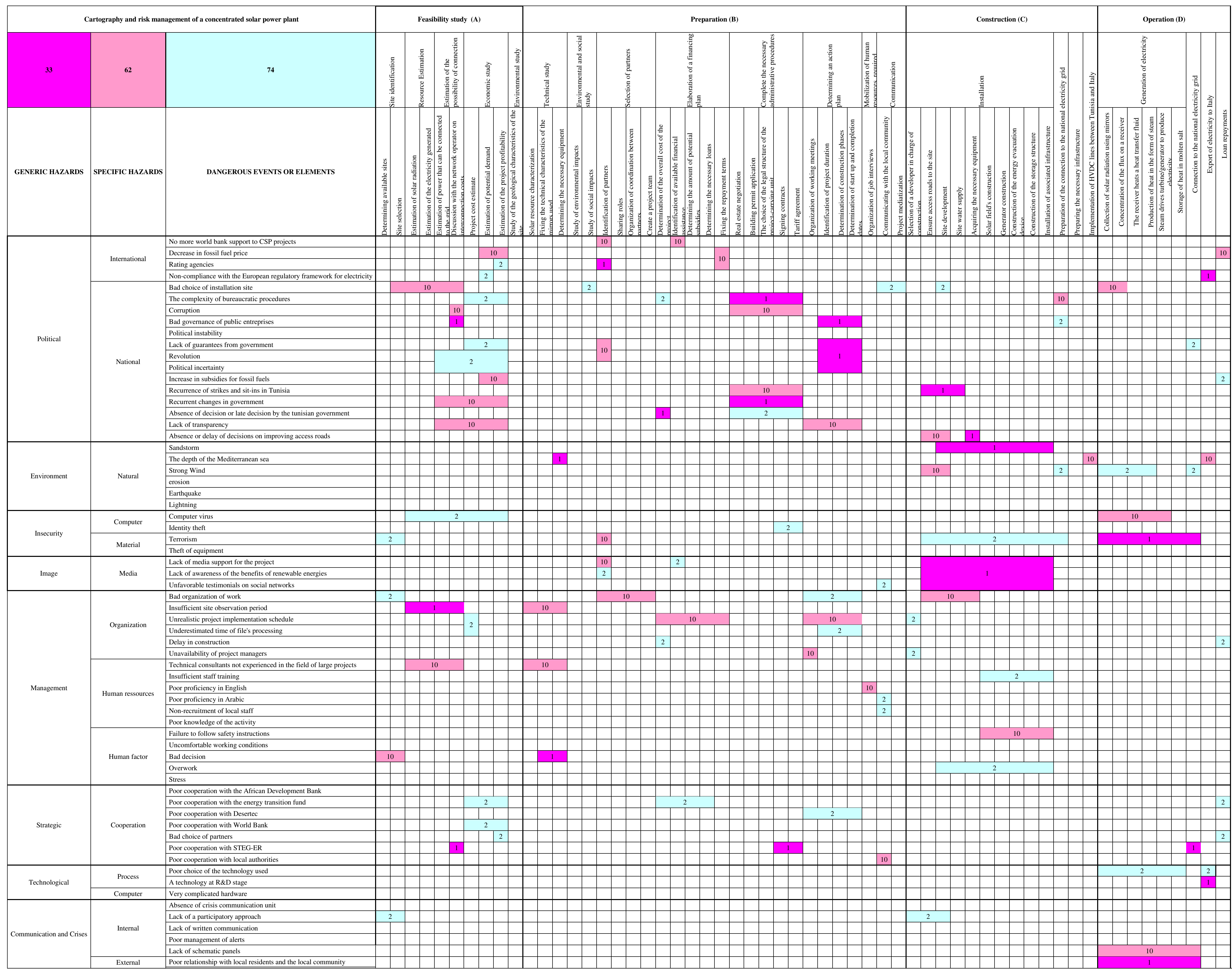




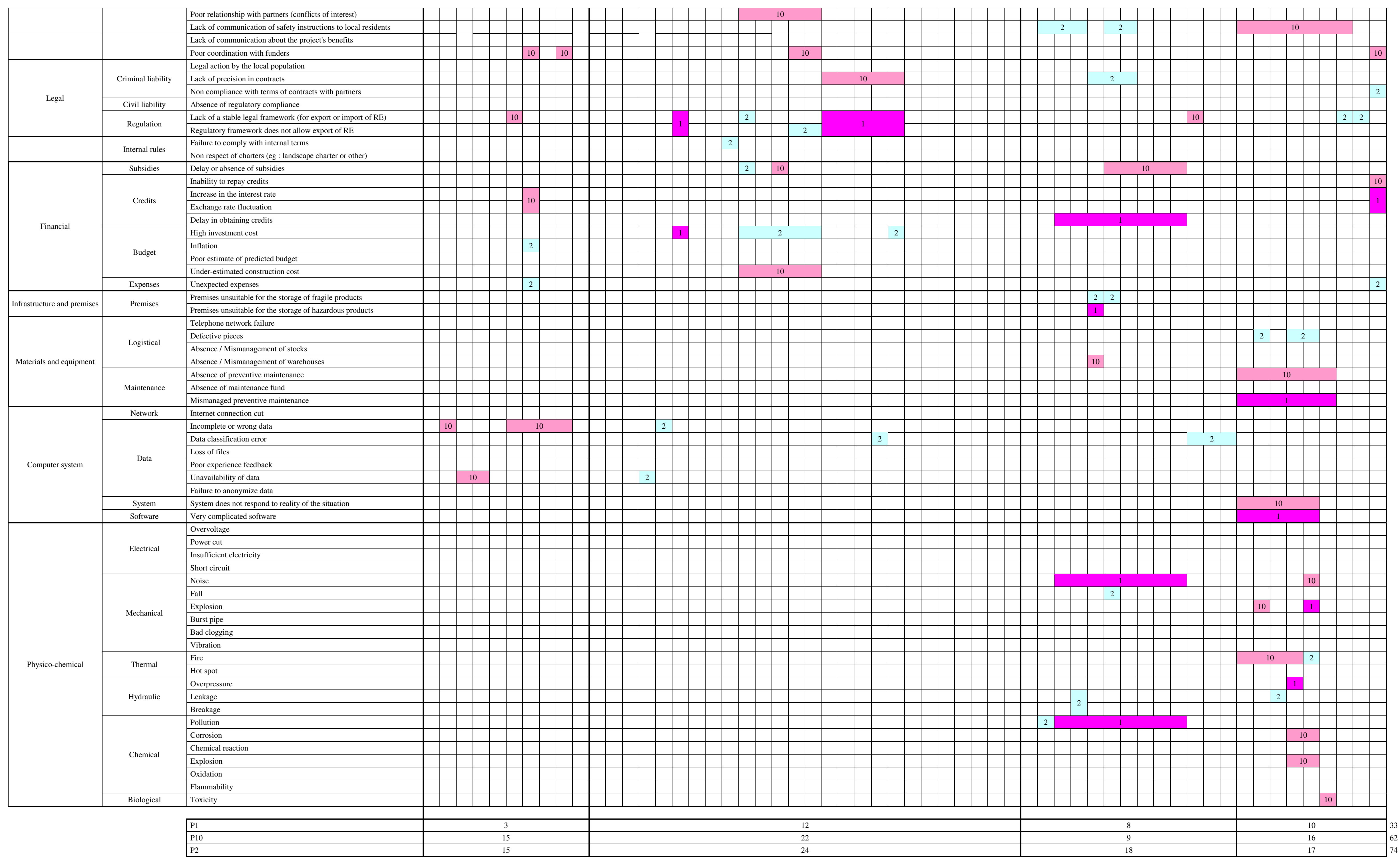


Appendix D. Scenario_GRA

\begin{tabular}{|c|c|c|c|c|c|c|c|c|c|c|c|c|c|c|c|c|}
\hline $\begin{array}{l}\text { Generic } \\
\text { Hazard }\end{array}$ & System & $\begin{array}{l}\text { Hazardous } \\
\text { Situation }\end{array}$ & Contact Cause & Unwanted Event & Trigger Cause & $\begin{array}{l}\text { Existing risk } \\
\text { treatments } \\
\text { including } \\
\text { detection or } \\
\text { alert means }\end{array}$ & Consequences & $\begin{array}{l}\mathrm{G} \\
\mathrm{i}\end{array}$ & $\begin{array}{l}\mathrm{L} \\
\mathrm{i}\end{array}$ & $\begin{array}{l}c \\
i\end{array}$ & $\begin{array}{l}\text { Risk reduction actions and } \\
\text { implementation accountable }\end{array}$ & PE & $\begin{array}{l}\mathbf{G} \\
\mathbf{r}\end{array}$ & $\mathbf{L}$ & $\begin{array}{l}C \\
r\end{array}$ & $\begin{array}{l}\text { Management of } \\
\text { residual risk }\end{array}$ \\
\hline POL & A & Slow procedures & $\begin{array}{l}\text { STEG is in a } \\
\text { monopoly } \\
\text { position }\end{array}$ & $\begin{array}{l}\text { Failure to obtain } \\
\text { a construction } \\
\text { permit }\end{array}$ & $\begin{array}{l}\text { The Tunisian } \\
\text { regulatory } \\
\text { framework does } \\
\text { not allow the } \\
\text { export of } \\
\text { renewable } \\
\text { energies }\end{array}$ & $\begin{array}{l}\text { Absence of } \\
\text { means }\end{array}$ & $\begin{array}{l}\text { 45Delay in project } \\
\text { implementation }\end{array}$ & 4 & 4 & 3 & $\begin{array}{l}\text { A1 A2 } \\
\text { A1: Initiate discussions with } \\
\text { government officials to change } \\
\text { the regulatory framework and } \\
\text { facilitate procedures with } \\
\text { STEG } \\
\text { A2: The formation of a team of } \\
\text { specialists to discuss all the } \\
\text { necessary points with the } \\
\text { STEG officials. }\end{array}$ & 2 & 4 & 2 & 2 & $\begin{array}{l}\text { P1 } \\
\text { P1: Continuous } \\
\text { monitoring of the } \\
\text { progress of } \\
\text { discussions with the } \\
\text { government }\end{array}$ \\
\hline MAN & A & $\begin{array}{l}\text { An erroneous } \\
\text { estimate of the } \\
\text { resource }\end{array}$ & $\begin{array}{l}\text { First experience } \\
\text { in the tunisian } \\
\text { desert }\end{array}$ & $\begin{array}{l}\text { Overestimation of } \\
\text { the project } \\
\text { performance }\end{array}$ & $\begin{array}{l}\text { A site } \\
\text { observation } \\
\text { period of less } \\
\text { than one year }\end{array}$ & $\begin{array}{l}\text { Absence of } \\
\text { means }\end{array}$ & $\begin{array}{l}54 \text { Huge financial } \\
\text { loss }\end{array}$ & 5 & 2 & 2 & $\begin{array}{l}\text { A3 A4 } \\
\text { A3: Requiring a site } \\
\text { observation period of one year } \\
\text { A4: Hiring experienced } \\
\text { professionals to assess the } \\
\text { total energy output of the } \\
\text { facility }\end{array}$ & 3 & 2 & 2 & 1 & \\
\hline POL & B & $\begin{array}{l}\text { The } \\
\text { discouragement of } \\
\text { private investors }\end{array}$ & $\begin{array}{l}\text { Degradation of } \\
\text { Tunisia's } \\
\text { sovereign rating } \\
\text { by rating } \\
\text { agencies }\end{array}$ & $\begin{array}{l}\text { Few financing } \\
\text { funds are } \\
\text { interested in a } \\
\text { project in Tunisia }\end{array}$ & $\begin{array}{l}\text { Political } \\
\text { instability }\end{array}$ & $\begin{array}{l}\text { Absence of } \\
\text { means }\end{array}$ & $\begin{array}{l}\text { 33Significant } \\
\text { operational } \\
\text { constraints }\end{array}$ & 3 & 4 & 2 & $\begin{array}{l}\text { A7 A8 } \\
\text { A7: The choice of solid } \\
\text { financial partners } \\
\text { A8: The cooperation with the } \\
\text { World Bank and the African } \\
\text { Development Bank }\end{array}$ & 2 & 2 & 3 & 1 & \\
\hline POL & B & $\begin{array}{l}\text { Slow } \\
\text { administrative } \\
\text { procedures }\end{array}$ & $\begin{array}{l}\text { Poor governance } \\
\text { of tunisian public } \\
\text { administrations }\end{array}$ & $\begin{array}{l}\text { Delay in granting } \\
\text { authorization for } \\
\text { the construction } \\
\text { of the solar } \\
\text { power plant }\end{array}$ & $\begin{array}{l}\text { Recurring } \\
\text { changes in } \\
\text { government }\end{array}$ & $\begin{array}{l}\text { Absence of } \\
\text { means }\end{array}$ & $\begin{array}{l}\text { 45Delay in project } \\
\text { implementation }\end{array}$ & 4 & 4 & 3 & $\begin{array}{l}\text { A9 A10 } \\
\text { A9: To form a team of tunisian } \\
\text { experts to accelerate } \\
\text { administrative procedures } \\
\text { A10: To prepare a plan } \\
\text { describing the procedures for } \\
\text { obtaining the various permits } \\
\text { and authorizations required }\end{array}$ & 2 & 3 & 3 & 2 & $\begin{array}{l}\text { P2 } \\
\text { P2 : To establish a } \\
\text { checklist of the } \\
\text { various permits and } \\
\text { authorizations } \\
\text { required }\end{array}$ \\
\hline
\end{tabular}




\begin{tabular}{|c|c|c|c|c|c|c|c|c|c|c|c|c|c|c|c|c|}
\hline POL & B & $\begin{array}{l}\text { An unreliable } \\
\text { action plan }\end{array}$ & $\begin{array}{l}\text { Lack of } \\
\text { transparency }\end{array}$ & $\begin{array}{l}\text { An unfeasible } \\
\text { action plan }\end{array}$ & $\begin{array}{l}\text { The tunisian } \\
\text { revolution }\end{array}$ & $\begin{array}{l}\text { Absence of } \\
\text { means }\end{array}$ & $\begin{array}{l}\text { 12Acceptable } \\
\text { operational } \\
\text { constraints } \\
\end{array}$ & 1 & 5 & 1 & & & & & & \\
\hline POL & B & $\begin{array}{l}\text { Lack of visibility in } \\
\text { the short and } \\
\text { medium term }\end{array}$ & $\begin{array}{l}\text { Political } \\
\text { uncertainty }\end{array}$ & $\begin{array}{l}\text { No detailed and } \\
\text { final action plan }\end{array}$ & $\begin{array}{l}\text { Regulatory } \\
\text { barriers }\end{array}$ & $\begin{array}{l}\text { Absence of } \\
\text { means }\end{array}$ & $\begin{array}{l}\text { 33Significant } \\
\text { operational } \\
\text { constraints }\end{array}$ & 3 & 4 & 2 & $\begin{array}{l}\text { A11 } \\
\text { A11: Continuous adjustment of } \\
\text { the action plan }\end{array}$ & 2 & 2 & 3 & 1 & \\
\hline POL & B & $\begin{array}{l}\text { Slow } \\
\text { administrative } \\
\text { procedures }\end{array}$ & $\begin{array}{l}\text { Lack of a clear } \\
\text { political } \\
\text { commitment for } \\
\text { renewable } \\
\text { energies } \\
\text { promotion }\end{array}$ & $\begin{array}{l}\text { An increase in } \\
\text { the project cost }\end{array}$ & $\begin{array}{l}\text { Lack of } \\
\text { transparency }\end{array}$ & $\begin{array}{l}\text { Absence of } \\
\text { means }\end{array}$ & $\begin{array}{l}\text { 31Unacceptable } \\
\text { performance } \\
\text { degradation }\end{array}$ & 3 & 5 & 3 & $\begin{array}{l}\text { A12 A13 } \\
\text { A12: The formation of a crisis } \\
\text { unit in charge of } \\
\text { communication with the } \\
\text { political decision-makers and } \\
\text { the public administrations } \\
\text { A13: To minimize expenses } \\
\text { during the preparation phase } \\
\text { (travel, premises...) }\end{array}$ & 2 & 3 & 3 & 2 & $\begin{array}{l}\text { P3 } \\
\text { P3 : To implement a } \\
\text { procedure for } \\
\text { continuous monitoring } \\
\text { and evaluation of } \\
\text { progress in } \\
\text { administrative } \\
\text { procedures }\end{array}$ \\
\hline POL & B & $\begin{array}{l}\text { An increase in the } \\
\text { project cost }\end{array}$ & $\begin{array}{l}\text { Increase in } \\
\text { spending }\end{array}$ & $\begin{array}{l}\text { Increase in } \\
\text { capital spending }\end{array}$ & $\begin{array}{l}\text { Lack of political } \\
\text { will }\end{array}$ & $\begin{array}{l}\text { Absence of } \\
\text { means }\end{array}$ & $\begin{array}{l}54 \text { Huge financial } \\
\text { loss }\end{array}$ & 5 & 3 & 3 & $\begin{array}{l}\text { A14 A15 } \\
\text { A14: Minimize all costs in the } \\
\text { preparation phase } \\
\text { A15: Decrease the number of } \\
\text { staff during the preparation } \\
\text { phase }\end{array}$ & 2 & 3 & 3 & 2 & $\begin{array}{l}\text { P4 } \\
\text { P4 : To establish a } \\
\text { plan for monitoring } \\
\text { the application of } \\
\text { austerity procedures }\end{array}$ \\
\hline MAN & B & $\begin{array}{l}\text { Wrong choice of } \\
\text { cooling system }\end{array}$ & $\begin{array}{l}\text { Taking into } \\
\text { account only the } \\
\text { environmental } \\
\text { aspect }\end{array}$ & $\begin{array}{l}\text { The choice of dry } \\
\text { cooling which is } \\
\text { less effective } \\
\text { than wet cooling }\end{array}$ & $\begin{array}{l}\text { Water scarcity } \\
\text { in the desert }\end{array}$ & $\begin{array}{l}\text { Absence of } \\
\text { means }\end{array}$ & $\begin{array}{l}\text { 33Significant } \\
\text { operational } \\
\text { constraints }\end{array}$ & 3 & 4 & 2 & $\begin{array}{l}\text { A17 } \\
\text { A17: Continuous monitoring of } \\
\text { the efficiency of dry cooling }\end{array}$ & 2 & 2 & 2 & 1 & \\
\hline STR & B & $\begin{array}{l}\text { Delay in signing } \\
\text { contracts }\end{array}$ & $\begin{array}{l}\text { STEG is in a } \\
\text { monopoly } \\
\text { position }\end{array}$ & $\begin{array}{l}\text { Failure to meet } \\
\text { deadlines }\end{array}$ & $\begin{array}{l}\text { Poor estimation } \\
\text { of file } \\
\text { processing time }\end{array}$ & $\begin{array}{l}\text { Absence of } \\
\text { means }\end{array}$ & $\begin{array}{l}\text { 33Significant } \\
\text { operational } \\
\text { constraints }\end{array}$ & 3 & 3 & 2 & $\begin{array}{l}\text { A18 } \\
\text { A18: Develop clear contracts } \\
\text { that define in detail the } \\
\text { responsibilities of each party }\end{array}$ & 2 & 2 & 3 & 1 & \\
\hline
\end{tabular}




\begin{tabular}{|c|c|c|c|c|c|c|c|c|c|c|c|c|c|c|c|c|}
\hline LEG & $B$ & $\begin{array}{l}\text { Difficulty to find } \\
\text { convenient } \\
\text { partners }\end{array}$ & $\begin{array}{l}\text { Political } \\
\text { instability }\end{array}$ & $\begin{array}{l}\text { Difficulty in } \\
\text { attracting private } \\
\text { investors }\end{array}$ & $\begin{array}{l}\text { Lack of a } \\
\text { regulatory } \\
\text { framework } \\
\text { which allows } \\
\text { the export of } \\
\text { renewable } \\
\text { energies }\end{array}$ & $\begin{array}{l}\text { Absence of } \\
\text { means }\end{array}$ & $\begin{array}{l}\text { 33Significant } \\
\text { operational } \\
\text { constraints }\end{array}$ & 3 & 5 & & $\begin{array}{l}\text { A19 A20 } \\
\text { A19: Accelerate discussions } \\
\text { with government } \\
\text { A 20: Organize seminars with } \\
\text { private investors and members } \\
\text { of government to discuss and } \\
\text { ensure the government's } \\
\text { willingness to change existing } \\
\text { regulations }\end{array}$ & 2 & 3 & 3 & 2 & $\begin{array}{l}\text { P5 } \\
\text { P5 : Put private } \\
\text { investors up to date } \\
\text { with all the advances } \\
\text { made in discussions } \\
\text { with the government }\end{array}$ \\
\hline LEG & $B$ & $\begin{array}{l}\text { Slow discussions } \\
\text { with policy makers }\end{array}$ & $\begin{array}{l}\text { Lack of political } \\
\text { will }\end{array}$ & $\begin{array}{l}\text { Failure to meet } \\
\text { deadlines }\end{array}$ & $\begin{array}{l}\text { Absence of firm } \\
\text { decision }\end{array}$ & $\begin{array}{l}\text { Absence of } \\
\text { means }\end{array}$ & $\begin{array}{l}\text { 45Delay in project } \\
\text { implementation }\end{array}$ & 4 & 4 & & $\begin{array}{l}\text { A21 A22 } \\
\text { A21: Intensify discussions with } \\
\text { policy makers to change } \\
\text { regulation } \\
\text { A22: Try to give the maximum } \\
\text { guarantees to the government } \\
\text { on the expected benefits of this } \\
\text { project on local employment }\end{array}$ & 2 & 3 & 3 & 2 & $\begin{array}{l}\text { P6 } \\
\text { P6 : Exercise } \\
\text { continuous control } \\
\text { over the progress of } \\
\text { the discussions and } \\
\text { the obstacles to be } \\
\text { overcome }\end{array}$ \\
\hline FIN & B & $\begin{array}{l}\text { Huge funding } \\
\text { requirement }\end{array}$ & A huge project & $\begin{array}{l}\text { Difficulty in } \\
\text { raising funds }\end{array}$ & $\begin{array}{l}\text { No participation } \\
\text { of the Tunisian } \\
\text { government in } \\
\text { the financing }\end{array}$ & $\begin{array}{l}\text { Absence of } \\
\text { means }\end{array}$ & $\begin{array}{l}\text { 45Delay in project } \\
\text { implementation }\end{array}$ & 4 & 4 & & $\begin{array}{l}\text { A23 A24 A25 } \\
\text { A23 : Construction by phases } \\
\text { A24: The recourse to the } \\
\text { World Bank } \\
\text { A25: The recourse to the } \\
\text { African Development Bank }\end{array}$ & 3 & 3 & 4 & 2 & $\begin{array}{l}\text { P7 P8 } \\
\text { P7 : Reduce } \\
\text { construction and } \\
\text { assembly costs } \\
\text { P8 : Reduce } \\
\text { maintenance costs }\end{array}$ \\
\hline POL & C & $\begin{array}{l}\text { Delay in delivery } \\
\text { of necessary } \\
\text { equipment }\end{array}$ & $\begin{array}{l}\text { Poor } \\
\text { Organisation }\end{array}$ & $\begin{array}{l}\text { Discontinuity in } \\
\text { the construction } \\
\text { phase }\end{array}$ & $\begin{array}{l}\text { recurring } \\
\text { interruptions in } \\
\text { the installation }\end{array}$ & $\begin{array}{l}\text { Absence of } \\
\text { means }\end{array}$ & $\begin{array}{l}\text { 33Significant } \\
\text { operational } \\
\text { constraints }\end{array}$ & 3 & 3 & 2 & $\begin{array}{l}\text { A26 A27 } \\
\text { A26: implement a preventive } \\
\text { action plan } \\
\text { A27: Recruit a stock manager }\end{array}$ & 2 & 3 & 2 & 1 & \\
\hline POL & C & $\begin{array}{l}\text { Access roads not } \\
\text { suitable for large } \\
\text { trucks }\end{array}$ & $\begin{array}{l}\text { The slowness of } \\
\text { procedures }\end{array}$ & Road accidents & $\begin{array}{l}\text { Road traffic due } \\
\text { to the } \\
\text { construction } \\
\text { site }\end{array}$ & $\begin{array}{l}\text { Absence of } \\
\text { means }\end{array}$ & $\begin{array}{l}23 \text { Injury on duty } \\
\text { with work } \\
\text { stoppage less } \\
\text { than } 21 \text { days }\end{array}$ & 2 & 4 & 2 & $\begin{array}{l}\text { A28 A29 A30 } \\
\text { A28: Organize handling } \\
\text { operations during off-peak } \\
\text { period } \\
\text { A29: Set up traffic signs and } \\
\text { signs of speed reduction } \\
\text { A30: Heavy and light vehicles } \\
\text { must show a recent technical } \\
\text { inspection } \\
\end{array}$ & 1 & 2 & 3 & 1 & \\
\hline ENV & C & $\begin{array}{l}\text { Hard working } \\
\text { conditions }\end{array}$ & $\begin{array}{l}\text { Absence of } \\
\text { barriers around } \\
\text { the site }\end{array}$ & $\begin{array}{l}\text { Temporary } \\
\text { cessation of work }\end{array}$ & $\begin{array}{l}\text { Lack of } \\
\text { permanent } \\
\text { drainage }\end{array}$ & $\begin{array}{l}\text { Absence of } \\
\text { means }\end{array}$ & $\begin{array}{l}\text { 45Delay in project } \\
\text { implementation }\end{array}$ & 4 & 4 & & $\begin{array}{l}\text { A31 A32 } \\
\text { A31: Establish barriers around } \\
\text { the site } \\
\text { A32: Inform drivers and } \\
\text { employees if weather forecasts } \\
\text { indicate the possibility of } \\
\text { sandstorms }\end{array}$ & 1 & 3 & 4 & 2 & $\begin{array}{l}\text { P9 P10 } \\
\text { P9: Permanent } \\
\text { drainage of the site } \\
\text { P10: Continuous } \\
\text { monitoring of weather } \\
\text { forecasts }\end{array}$ \\
\hline
\end{tabular}




\begin{tabular}{|c|c|c|c|c|c|c|c|c|c|c|c|c|c|c|c|c|}
\hline IMG & C & $\begin{array}{l}\text { Confrontations } \\
\text { with local } \\
\text { residents who are } \\
\text { against the } \\
\text { installation }\end{array}$ & $\begin{array}{l}\text { Lack of } \\
\text { participatory } \\
\text { approach }\end{array}$ & $\begin{array}{l}\text { Conflicts of } \\
\text { interest }\end{array}$ & $\begin{array}{l}\text { The existence } \\
\text { of inhabitants } \\
\text { who use the } \\
\text { site for camels }\end{array}$ & $\begin{array}{l}\text { Absence of } \\
\text { means }\end{array}$ & $\begin{array}{l}\text { 33Significant } \\
\text { operational } \\
\text { constraints }\end{array}$ & 3 & 4 & 2 & $\begin{array}{l}\text { A33 A34 A35 } \\
\text { A33: Collaboration with local } \\
\text { authorities } \\
\text { A34: Setting up focus groups } \\
\text { A35: Inform the shepherds at } \\
\text { the beginning of the project to } \\
\text { adapt the movements of their } \\
\text { flocks }\end{array}$ & 1 & 2 & 3 & 1 & \\
\hline FIN & C & Funding difficulties & $\begin{array}{l}\text { Non-compliance } \\
\text { with project } \\
\text { specifications }\end{array}$ & $\begin{array}{l}\text { Failure to meet } \\
\text { construction } \\
\text { deadlines }\end{array}$ & $\begin{array}{l}\text { Temporary stop } \\
\text { of the } \\
\text { construction }\end{array}$ & $\begin{array}{l}\text { Absence of } \\
\text { means }\end{array}$ & $\begin{array}{l}\text { 45Delay in project } \\
\text { implementation }\end{array}$ & 4 & 4 & 3 & $\begin{array}{l}\text { A36 } \\
\text { A36: Prepare an activity report } \\
\text { and an interim financial report } \\
\text { every six months }\end{array}$ & 2 & 3 & 3 & 2 & $\begin{array}{l}\text { P } 11 \\
\text { P11: Financial audit } \\
\text { to ensure conformity } \\
\text { between the } \\
\text { specifications, } \\
\text { progress of } \\
\text { implementation, } \\
\text { disbursements and } \\
\text { loan agreement }\end{array}$ \\
\hline INF & C & $\begin{array}{l}\text { The existence of } \\
\text { hazardous } \\
\text { products in } \\
\text { warehouses }\end{array}$ & $\begin{array}{l}\text { Storage of fossil } \\
\text { fuels and molten } \\
\text { salt }\end{array}$ & Soil pollution & Leakage & $\begin{array}{l}\text { Absence of } \\
\text { means }\end{array}$ & $\begin{array}{l}\text { 24Controllable } \\
\text { pollution }\end{array}$ & 2 & 4 & 2 & $\begin{array}{l}\text { A37 A38 } \\
\text { A37: Impervious storage area } \\
\text { which is equipped with } \\
\text { retention of adequate volumes } \\
\text { A38: Develop an } \\
\text { environmental monitoring } \\
\text { program }\end{array}$ & 1 & 1 & 3 & 1 & \\
\hline $\mathrm{PCH}$ & C & Noise & $\begin{array}{l}\text { Significant } \\
\text { equipment } \\
\text { requirements }\end{array}$ & $\begin{array}{l}\text { Difficult working } \\
\text { conditions }\end{array}$ & $\begin{array}{l}\text { Increase in dust } \\
\text { and releases to } \\
\text { air }\end{array}$ & $\begin{array}{l}\text { Absence of } \\
\text { means }\end{array}$ & $\begin{array}{l}23 \text { Injury on duty } \\
\text { with work } \\
\text { stoppage less } \\
\text { than } 21 \text { days }\end{array}$ & 2 & 4 & 2 & $\begin{array}{l}\text { A39 A40 A41 } \\
\text { A39: Keep vehicles of the } \\
\text { construction site in good } \\
\text { condition } \\
\text { A40: Equipping workers with } \\
\text { acoustic protection } \\
\text { A41: Watering of the access } \\
\text { roads to limit the dust lifting }\end{array}$ & 1 & 1 & 3 & 1 & \\
\hline $\mathrm{PCH}$ & C & $\begin{array}{l}\text { Degradation of air } \\
\text { quality }\end{array}$ & $\begin{array}{l}\text { Machines and } \\
\text { trucks }\end{array}$ & Air pollution & $\begin{array}{l}\text { Long } \\
\text { construction } \\
\text { time }\end{array}$ & $\begin{array}{l}\text { Absence of } \\
\text { means }\end{array}$ & $\begin{array}{l}\text { 43Significant } \\
\text { damage to the } \\
\text { environment }\end{array}$ & 4 & 3 & 2 & $\begin{array}{l}\text { A42 A43 A44 } \\
\text { A42: Construction site } \\
\text { machinery and trucks must be } \\
\text { well maintained } \\
\text { A43: Trucks must comply with } \\
\text { current exhaust-gas emission } \\
\text { laws } \\
\text { A44: Implementation of a } \\
\text { specification relating to the } \\
\text { standards of the construction } \\
\text { site }\end{array}$ & 1 & 3 & 2 & 1 & \\
\hline
\end{tabular}




\begin{tabular}{|c|c|c|c|c|c|c|c|c|c|c|c|c|c|c|c|}
\hline POL & D & $\begin{array}{l}\text { Non-compliance } \\
\text { with the electricity } \\
\text { purchasing } \\
\text { regulations of } \\
\text { european } \\
\text { countries }\end{array}$ & $\begin{array}{l}\text { Lack of follow-up } \\
\text { of all changes in } \\
\text { European } \\
\text { legislation }\end{array}$ & $\begin{array}{l}\text { Temporary } \\
\text { cessation of } \\
\text { activity }\end{array}$ & $\begin{array}{l}\text { Slow } \\
\text { discussions }\end{array}$ & $\begin{array}{l}\text { Absence of } \\
\text { means }\end{array}$ & $\begin{array}{l}\text { 33Significant } \\
\text { operational } \\
\text { constraints }\end{array}$ & 3 & \multicolumn{2}{|c|}{32} & $2 \mid \begin{array}{l}\text { A45 } \\
\text { A45 : A detailed analysis of all } \\
\text { the opportunities and threats } \\
\text { presented in the various } \\
\text { countries interested in buying } \\
\text { the electricity produced }\end{array}$ & 2 & 2 & \multicolumn{2}{|c|}{\begin{tabular}{l|l}
3 & 1
\end{tabular}} \\
\hline INS & $D$ & $\begin{array}{l}\text { The possibility of } \\
\text { acts of violence by } \\
\text { extremists }\end{array}$ & $\begin{array}{l}\text { The existence of } \\
\text { extremist groups } \\
\text { that are against } \\
\text { foreign } \\
\text { companies }\end{array}$ & $\begin{array}{l}\text { Delay in project } \\
\text { implementation }\end{array}$ & $\begin{array}{l}\text { Lack of political } \\
\text { stability }\end{array}$ & $\begin{array}{l}\text { Absence of } \\
\text { means }\end{array}$ & $\begin{array}{l}\text { 34Significant } \\
\text { damage to } \\
\text { infrastructure or } \\
\text { goods }\end{array}$ & 3 & 3 & 2 & $\begin{array}{l}\text { A46 A47 A48 } \\
\text { A46 : Regular communication } \\
\text { between project } \\
\text { representatives and local } \\
\text { stakeholders } \\
\text { A47: Create a positive } \\
\text { perception of the project } \\
\text { (employment, reputation of the } \\
\text { city ...) } \\
\text { A48: Underwriting political risk } \\
\text { insurance with the Multilateral } \\
\text { Investment Guarantee Agency } \\
\text { (World Bank) }\end{array}$ & 2 & 2 & 2 & 1 \\
\hline STR & $D$ & $\begin{array}{l}\text { Bad service of } \\
\text { STEG }\end{array}$ & $\begin{array}{l}\text { Absence of } \\
\text { clauses that } \\
\text { penalize STEG in } \\
\text { case of bad } \\
\text { service }\end{array}$ & $\begin{array}{l}\text { Recurrence of } \\
\text { conflicts }\end{array}$ & $\begin{array}{l}\text { Lack of } \\
\text { precision in } \\
\text { contracts }\end{array}$ & $\begin{array}{l}\text { Absence of } \\
\text { means }\end{array}$ & $\begin{array}{l}\text { 31Unacceptable } \\
\text { performance } \\
\text { degradation }\end{array}$ & 3 & 4 & 2 & $\begin{array}{l}\text { A49 } \\
\text { A49: Define clearly the } \\
\text { responsibilities and penalties } \\
\text { of each party in case of non- } \\
\text { compliance with commitments }\end{array}$ & 1 & 2 & 3 & 1 \\
\hline TEC & $\mathrm{D}$ & $\begin{array}{l}\text { Not achieving } \\
\text { desired } \\
\text { performance }\end{array}$ & $\begin{array}{l}\text { HVDC cables } \\
\text { never used for } \\
\text { this depth }\end{array}$ & $\begin{array}{l}\text { Non-compliance } \\
\text { with } \\
\text { commitments }\end{array}$ & $\begin{array}{l}\text { Technology in } \\
\text { research and } \\
\text { development } \\
\text { phase }\end{array}$ & $\begin{array}{l}\text { Absence of } \\
\text { means }\end{array}$ & $\begin{array}{l}32 \text { Very degraded } \\
\text { or failed activity }\end{array}$ & 3 & 3 & 2 & $\begin{array}{l}\text { A50 } \\
\text { A50: The recourse to known } \\
\text { manufacturers to manufacture } \\
\text { cables that support this depth }\end{array}$ & 2 & 3 & 1 & 1 \\
\hline MAT & $D$ & $\begin{array}{l}\text { Decrease in the } \\
\text { frequency of } \\
\text { preventive } \\
\text { maintenance }\end{array}$ & $\begin{array}{l}\text { Cost reduction } \\
\text { strategy }\end{array}$ & $\begin{array}{l}\text { Recurrence of } \\
\text { breakdowns }\end{array}$ & $\begin{array}{l}\text { Absence of a } \\
\text { maintenance } \\
\text { fund }\end{array}$ & $\begin{array}{l}\text { Absence of } \\
\text { means }\end{array}$ & $\begin{array}{l}21 \text { Unavailability of } \\
\text { services or } \\
\text { equipment on the } \\
\text { scheduled date }\end{array}$ & 2 & 4 & 2 & $\begin{array}{l}\text { A51 A52 } \\
\text { A51: The creation of a } \\
\text { maintenance fund } \\
\text { A52: A maintenance plan will } \\
\text { be established annually and } \\
\text { updated monthly }\end{array}$ & 2 & 1 & 3 & 1 \\
\hline FIN & $D$ & $\begin{array}{l}\text { Inability to repay } \\
\text { credits }\end{array}$ & $\begin{array}{l}\text { Exchange rate } \\
\text { and interest rate } \\
\text { fluctuations }\end{array}$ & $\begin{array}{l}\text { The increase in } \\
\text { debts }\end{array}$ & Economic crisis & $\begin{array}{l}\text { Absence of } \\
\text { means }\end{array}$ & $\begin{array}{l}54 \text { Huge financial } \\
\text { loss }\end{array}$ & 5 & 2 & 2 & $\begin{array}{l}\text { A53 A54 } \\
\text { A53: Conclude a SWAP } \\
\text { contract } \\
\text { A54: Conclude a contract of } \\
\text { Forward Rate Agreement } \\
\end{array}$ & 3 & 3 & 2 & 1 \\
\hline CS & $D$ & $\begin{array}{l}\text { Fault on the part } \\
\text { of employees }\end{array}$ & $\begin{array}{l}\text { Short training } \\
\text { period }\end{array}$ & $\begin{array}{l}\text { Recurrence of } \\
\text { mistakes }\end{array}$ & $\begin{array}{l}\text { The language } \\
\text { used is English }\end{array}$ & $\begin{array}{l}\text { Absence of } \\
\text { means }\end{array}$ & $\begin{array}{l}\text { 31Unacceptable } \\
\text { performance } \\
\text { degradation }\end{array}$ & 3 & 4 & 2 & $\begin{array}{l}\text { A55 } \\
\text { A55: Require excellent } \\
\text { knowledge of English }\end{array}$ & 1 & 1 & 3 & 1 \\
\hline
\end{tabular}




\begin{tabular}{|c|c|c|c|c|c|c|c|c|c|c|c|c|c|c|c|c|}
\hline $\mathrm{PCH}$ & D & $\begin{array}{l}\text { The use of fossil } \\
\text { fuels }\end{array}$ & $\begin{array}{l}\text { Keep molten salt } \\
\text { at high } \\
\text { temperature }\end{array}$ & Fire & Leakage & $\begin{array}{l}\text { Absence of } \\
\text { means }\end{array}$ & $\begin{array}{l}\text { 42Partial } \\
\text { destruction of } \\
\text { infrastructure or } \\
\text { assets }\end{array}$ & 4 & 3 & 2 & $\begin{array}{l}\text { A56 A57 A58 A59 } \\
\text { A56: Absorbent material will be } \\
\text { available near the transformer } \\
\text { and warehouses } \\
\text { A57: No smoking } \\
\text { A58: Installation of fire } \\
\text { extinguishers } \\
\text { A59: Underwriting of fire } \\
\text { insurance }\end{array}$ & 3 & 3 & 2 & 1 & \\
\hline $\mathrm{PCH}$ & D & $\begin{array}{l}\text { Pressure and } \\
\text { heated running of } \\
\text { the tribune }\end{array}$ & $\begin{array}{l}\text { Existence of high } \\
\text { pressure steam }\end{array}$ & Explosion & $\begin{array}{l}\text { The presence } \\
\text { of flame or fire }\end{array}$ & $\begin{array}{l}\text { Absence of } \\
\text { means }\end{array}$ & $\begin{array}{l}\text { 52Total } \\
\text { destruction of } \\
\text { infrastructure or } \\
\text { assets }\end{array}$ & 5 & 3 & 3 & $\begin{array}{l}\text { A60 A61 A62 A63 } \\
\text { A60: Electrical appliances } \\
\text { A61: No smoking } \\
\text { A62: Installation of fire } \\
\text { extinguishers } \\
\text { A63: Develop a fire safety } \\
\text { management plan }\end{array}$ & 3 & 4 & 2 & 2 & $\begin{array}{l}\text { P12 P13 } \\
\text { P12: Access to the } \\
\text { construction site } \\
\text { prohibited to the } \\
\text { public P13: A buffer } \\
\text { zone of at least } 10 \mathrm{~m} \\
\text { wide will surround the } \\
\text { entire project }\end{array}$ \\
\hline COM & D & $\begin{array}{l}\text { The lack of } \\
\text { acceptance of } \\
\text { local residents }\end{array}$ & $\begin{array}{l}\text { The noise of the } \\
\text { building site }\end{array}$ & $\begin{array}{l}\text { Complaints from } \\
\text { local residents }\end{array}$ & Road traffic & $\begin{array}{l}\text { Inform local } \\
\text { residents of } \\
\text { the start of } \\
\text { the work } \\
\text { and the } \\
\text { duration }\end{array}$ & $\begin{array}{l}\text { 33Significant } \\
\text { operational } \\
\text { constraints }\end{array}$ & 3 & 4 & 2 & $\begin{array}{l}\text { A64 A65 } \\
\text { A64: Set up a complaint } \\
\text { management unit for local } \\
\text { residents A65: } \\
\text { Use local human resources } \\
\text { who have the required skills }\end{array}$ & 1 & 3 & 2 & 1 & \\
\hline
\end{tabular}

